\title{
Experiments to Test the Role of Phosphatidylinositol 4,5-Bisphosphate in Neurotransmitter-Induced M-Channel Closure in Bullfrog Sympathetic Neurons
}

\author{
Christopher P. Ford, ${ }^{2}$ Patrick L. Stemkowski, ${ }^{1}$ Peter E. Light, ${ }^{1}$ and Peter A. Smith ${ }^{1,2}$ \\ ${ }^{1}$ Department of Pharmacology and ${ }^{2}$ Centre for Neuroscience, University of Alberta, Edmonton, Alberta, Canada T6G 2H7
}

\begin{abstract}
Various neurotransmitters excite neurons by suppressing a ubiquitous, voltage-dependent, noninactivating $\mathrm{K}^{+}$conductance called the M-conductance $\left(\mathrm{g}_{\mathrm{M}}\right)$. In bullfrog sympathetic ganglion neurons the suppression of $\mathrm{g}_{\mathrm{M}}$ by the P2Y agonist ATP involves phospholipase C (PLC). The present results are consistent with the involvement of the lipid and inositol phosphate cycles in the effects of both P2Y and muscarinic cholinergic agonists on $\mathrm{g}_{\mathrm{M}}$. Impairment of resynthesis of phosphatidylinositol 4,5-bisphosphate $\left(\mathrm{PIP}_{2}\right)$ with the phosphatidylinositol 4-kinase inhibitor wortmannin $(10 \mu \mathrm{M})$ slowed or blocked the recovery of agonist-induced $\mathrm{g}_{\mathrm{M}}$ suppression. This effect could not be attributed to an action of wortmannin on myosin light chain kinase or on phosphatidylinositol 3-kinase. Inhibition of PIP ${ }_{2}$ synthesis at an earlier point in the lipid cycle by the use of R59022 (40 $\mu \mathrm{M})$ to inhibit diacylglycerol kinase also slowed the rate of recovery of successive ATP responses. This effect required several applications of agonist to deplete levels of various phospholipid intermediates in the lipid cycle. PIP ${ }_{2}$ antibodies attenuated the suppression of $\mathrm{g}_{\mathrm{M}}$ by agonists. Intracellular application of $20 \mu \mathrm{M}$ PIP $_{2}$ slowed the rundown of KCNQ2/3 currents expressed in COS-1 or tsA-201 cells, and $100 \mu \mathrm{M} \mathrm{PIP}_{2}$ produced a small potentiation of native M-current bullfrog sympathetic neurons. These are the results that might be expected if agonist-induced activation of PLC and the concomitant depletion of PIP $_{2}$ contribute to the excitatory action of neurotransmitters that suppress $\mathrm{g}_{\mathrm{M}}$.
\end{abstract}

Key words: KCNQ; $\mathrm{G}_{\mathrm{q} / 11}$; phospholipase C; lipid kinase; M-current; P2Y

\section{Introduction}

The $\mathrm{M}$-conductance $\left(\mathrm{g}_{\mathrm{M}}\right)$ is a noninactivating, voltage- and timedependent $\mathrm{K}^{+}$conductance (Brown and Adams, 1980) that represents the product of $\mathrm{KCNQ} 2 / 3$ genes (Wang et al., 1998). Suppression of this conductance by neurotransmitters that act via $\mathrm{Gq} / \mathrm{G}_{11}$ produces excitatory effects in a variety of neuron types (Caulfield et al., 1994; Marrion, 1997; Cruzblanca et al., 1998; Haley et al., 1998). Although bradykinin inhibits $g_{M}$ in rat sympathetic neurons via phospholipase $\mathrm{C}$ (PLC) and $\mathrm{Ca}^{2+}$ release from inositol trisphosphate $\left(\mathrm{InsP}_{3}\right)$-sensitive stores (Cruzblanca et al., 1998), this transduction mechanism does not explain the actions of other neurotransmitters hitherto studied (Pfaffinger et al., 1988; Brown et al., 1989; Selyanko et al., 1990; Marrion, 1997; Stemkowski et al., 2002; Suh and Hille, 2002).

The P2Y agonists ATP and UTP suppress $\mathrm{g}_{\mathrm{M}}$ in both amphibian (Groul et al., 1981; Adams et al., 1982a) and mammalian sympathetic neurons (Bofill-Cardona et al., 2000). In both cell types the inhibition is reduced by the PLC inhibitor U73122, implying a role for phosphatidylinositol 4,5-bisphosphate $\left(\mathrm{PIP}_{2}\right)$ hydrolysis. In rat neurons available evidence suggests that inhibi-

Received Feb. 11, 2003; revised April 2, 2003; accepted April 4, 2003.

This work was supported by the Canadian Institutes for Health Research (MOP 57798). C.P.F. received studentship support from the Alberta Heritage Foundation for Medical Research and Neuroscience Canada. We thank Dr.

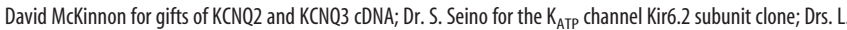
Aguilar Bryan and J. Bryan for the SUR1 subunit clone; Diana Steckley, Lynn Eisner, and Kenneth Wong for technical assistance; Dr. Jocelyn Manning Fox for useful discussions and advice on experimental procedures; and Drs. Bill Colmers and Fred Tse for their comments on a previous version of this manuscript.

Correspondence should be addressed to Peter A. Smith, Department of Pharmacology, 9.75 Medical Sciences Building, University of Alberta, Edmonton, Alberta, Canada T6G 2H7. E-mail peter.a.smith@ualberta.ca. Copyright $\odot 2003$ Society for Neuroscience $\quad$ 0270-6474/03/234931-11\$15.00/0 tion results from the consequential formation of $\mathrm{InsP}_{3}$ and the subsequent release of $\mathrm{Ca}^{2+}$ (Bofill-Cardona et al., 2000). However, in frog neurons neither $\mathrm{InsP}_{3}$ or $\mathrm{Ca}^{2+}$ nor the other consequential pathway for $\mathrm{PIP}_{2}$ hydrolysis, activation of protein kinase C (PKC), appears to be involved (Stemkowski et al., 2002). This raises the possibility that ATP-induced $g_{M}$ suppression in bullfrog sympathetic ganglion (BFSG) neurons involves signaling via the PLC-induced depletion of $\mathrm{PIP}_{2}$. This type of "upstream" signaling from PLC underlies agonist modulation of $\mathrm{Ca}^{2+}$ permeant TRPM7 channels in cardiac myocytes (Runnels et al., 2002), $\mathrm{K}_{\mathrm{ATP}}$ channels expressed in COS7 cells (Xie et al., 1999), and voltage-gated $\mathrm{Ca}^{2+}$ channels (Wu et al., 2002). Indeed, recent data suggest that a reduction in $\mathrm{PIP}_{2}$ concentration, as would occur after PLC activation (Willars et al., 1998), also could be responsible for agonist-induced closure of KCNQ2/3 channels expressed in Xenopus oocytes or Chinese hamster ovary (CHO) cells (Zhang et al., 2003). Because $\mathrm{PIP}_{2}$ increases putative $\mathrm{M}$-channel activity in rat sympathetic neurons, this mechanism also may control $\mathrm{g}_{\mathrm{M}}$ in intact neurons (Zhang et al., 2003). Moreover, ATP-dependent resynthesis of $\mathrm{PIP}_{2}$ is required for the recovery of muscarinic suppression of $\mathrm{g}_{\mathrm{M}}$ in the same cell type. This implies that an agonist-induced reduction in $\mathrm{PIP}_{2}$ may have been responsible for $\mathrm{M}$-channel closure in the first place (Suh and Hille, 2002). This emerging concept has been referred to as the "lipid kinase and PI-polyphosphate hypothesis" (Suh and Hille, 2002).

The results of the present experiments with enzyme inhibitors, $\mathrm{PIP}_{2}$ antibodies, and $\mathrm{PIP}_{2}$ itself are mainly consistent with the general lipid kinase and PI-polyphosphate hypothesis (Suh and Hille, 2002; Zhang et al., 2003). The specific findings are 
Table 1. Effect of kinase inhibitors on time for $50 \%$ recovery of ATP responses

\begin{tabular}{|c|c|c|c|}
\hline & $\begin{array}{l}\text { Control time for } \\
50 \% \text { recovery }(\mathrm{s})\end{array}$ & Time for $50 \%$ recovery after 5 min in inhibitor(s) & Change (\%) \\
\hline Wortmannin $(10 \mu \mathrm{M}$, whole cell; $n=11)$ & $19.7 \pm 2.5$ & $198.1 \pm 33.5(p<0.0005)(p<0.003$ vs untreated $)$ & 905 \\
\hline Wortmannin (10 $\mu \mathrm{M}$, perforated patch; $n=7)$ & $22.3 \pm 2.7$ & $144.9 \pm 41.9(p<0.04)(p<0.04$ vs untreated $)$ & 549 \\
\hline LY294002 (10 $\mu$ m, whole cell; $n=6)$ & $22.0 \pm 2.7$ & $36.2 \pm 4.8(p<0.05)$ (n.s. vs untreated) & 64 \\
\hline LY294002 (10 $\mu \mathrm{m}$, perforated patch; $n=5)$ & $21.6 \pm 3.8$ & $19.0 \pm 2.3$ (n.s.) (n.s. vs untreated) & -9 \\
\hline ML-7 (10 $\mu \mathrm{m}$, whole cell; $n=3)$ & $17.3 \pm 3.5$ & $27.3 \pm 5.2(p<0.05)$ (n.s. vs untreated) & 57 \\
\hline Untreated, 0.1\% DMSO control, whole cell $(n=9)$ & $26.9 \pm 9.8$ & $30.1 \pm 5.1$ (n.s.) & 12 \\
\hline Untreated, $0.1 \%$ DMSO control, perforated patch $(n=5)$ & $21.8 \pm 4.7$ & $23.2 \pm 6.5$ (n.s.) & 6 \\
\hline
\end{tabular}

Paired $t$ tests were used to compare recovery times before and after application of inhibitors to individual cells. Unpaired $t$ tests were used to compare differences between inhibitor-treated and untreated groups. n.s., Not significant.

explicable in terms of the hypothesis that PLC-mediated depletion of $\mathrm{PIP}_{2}$ mediates $\mathrm{g}_{\mathrm{M}}$ suppression by $\mathrm{P} 2 \mathrm{Y}$ agonists in BFSG neurons (Stemkowski et al., 2002). Moreover, this hypothesis also may explain the classical defining effect of muscarinic agonists on $g_{M}$ in BFSG (Brown and Adams, 1980).

A preliminary report of this work has appeared (Ford et al., 2002).

\section{Materials and Methods}

Animals were cared for in accordance with the principles and guidelines of the Canadian Council on Animal Care, and experimental protocols were approved by the Health Sciences Animal Welfare Committee of the University of Alberta.

BFSG experiments. Neurons in the seventh to tenth paravertebral sympathetic ganglia of male or female Rana catesbeiana were dissociated with trypsin and collagenase as previously described (Selyanko et al., 1990; Kurenny et al., 1994). Experiments were done on neurons that were maintained for 1-2 $\mathrm{d}$ in a culture medium that consisted of diluted L-15 medium (73\%) supplemented with $10 \mathrm{~mm}$ glucose, $1 \mathrm{~mm} \mathrm{CaCl}, 100$ $\mathrm{U} / \mathrm{ml}$ penicillin, $100 \mu \mathrm{g} / \mathrm{ml}$ streptomycin, and $10 \mu \mathrm{M}$ cytosine arabinoside. Electrophysiological recordings were done at $\sim 20^{\circ} \mathrm{C}$ via whole-cell or nystatin-perforated patch recording (Stemkowski et al., 2002) (Axoclamp 1B amplifier, pClamp 5.5. software, Axon Instruments, Foster City, $\mathrm{CA}$ ). Resting membrane potential was -50 to $-55 \mathrm{mV}$, and cells were held at $-30 \mathrm{mV}$. Experiments with agonists (ATP, UTP, and muscarine) were performed on B-cells $\left(C_{\text {in }}>30 \mathrm{pF}\right)$, whereas $\mathrm{PIP}_{2}$ was introduced into the smaller C-cells $\left(C_{\text {in }}<25 \mathrm{pF}\right)$ of BFSG (Dodd and Horn, 1983; Kurenny et al., 1994). Because the currents to be recorded were usually $<0.5 \mathrm{nA}$, no corrections were made for the voltage drop across the series resistance (Selyanko et al., 1990). Current-voltage relationships were obtained by using a $4.5 \mathrm{sec}$ ramp command from the holding potential of -30 to $-110 \mathrm{mV}(\sim 18 \mathrm{mV} / \mathrm{sec})$. Leak current $\left(I_{\mathrm{L}}\right)$ at $-30 \mathrm{mV}$ was estimated by extrapolation of the $I-V$ plot obtained at voltages between -75 and $-90 \mathrm{mV}$. The percentage of agonist-induced $\mathrm{g}_{\mathrm{M}}$ suppression was calculated as in our previous work (Stemkowski et al., 2002). Extracellular solution contained (in $\mathrm{mm}$ ): $113 \mathrm{NaCl}, 6 \mathrm{KCl}, 2 \mathrm{MgCl}_{2}, 2 \mathrm{CaCl}_{2}, 5$ HEPES/NaOH, pH 7.2, and 10 D-glucose. Patch pipettes had direct current resistances of 3-10 M $\Omega$. The pipette solution contained (in mM): 110 $\mathrm{KCl}, 10 \mathrm{NaCl}, 2 \mathrm{MgCl}_{2}, 0.4 \mathrm{CaCl}_{2}$, 4.4 EGTA, 5 HEPES/KOH, pH 6.7, 10 D-glucose, and $2 \mathrm{Na}_{2} \mathrm{ATP}(\mathrm{pCa}=7$ ) (Selyanko et al., 1990). Intracellular ATP was omitted in experiments in which the effect of $\mathrm{PIP}_{2}$ was examined.

Experiments on tsA-201 cells. tsA-201 or COS-1 cells were maintained in DMEM supplemented with $2 \mathrm{mM} \mathrm{L-glutamine,} 10 \%$ fetal calf serum, and $0.1 \%$ penicillin/streptomycin at $37^{\circ} \mathrm{C}$ with $10 \% \mathrm{CO}_{2}$. KCNQ2 and KCNQ3 channel subunit clones were kindly provided by Dr. D. McKinnon (State University of New York, Stony Brook, NY). Cells were plated at $\sim 40-70 \%$ confluency on $35 \mathrm{~mm}$ dishes $4-6 \mathrm{hr}$ before transfection. Clones were inserted into the mammalian expression vector pCDNA3 and transfected into COS- 1 cells by using Lipofectamine reagent per the manufacturer's instructions (Invitrogen, San Diego, CA) or into tsA-201 cells by using the calcium phosphate precipitation technique. For expression of heteromultimers a 1:1 molar ratio of KCNQ2 and KCNQ3 CDNA was transfected. Successfully transfected cells were identified by coexpression of the green fluorescent protein plasmid (pGreen Lantern, In- vitrogen), visualized via fluorescence optics. Recordings were made at $48-72$ or $72-96 \mathrm{hr}$ after transfecting for COS-1 or tsA-201 cells, respectively, in whole-cell mode with 2-6 $\mathrm{M} \Omega$ electrodes. Data were acquired with pClamp software (version 8.0), using an Axopatch 200B amplifier (Axon Instruments), and were filtered at $2 \mathrm{kHz}$. Capacitance transients were canceled by using circuitry within the amplifier, and the series resistance compensation was set at $40-60 \%$. Whole-cell recordings from transfected cells were made at $\sim 20^{\circ} \mathrm{C}$, using an extracellular solution consisting of (in mM): $144 \mathrm{NaCl}, 2.5 \mathrm{KCl}, 2 \mathrm{CaCl}_{2}, 0.5 \mathrm{MgCl}_{2}, 5$ HEPES, and 10 D-glucose, $\mathrm{pH} 7.4$, and an intracellular solution consisting of (in $\mathrm{mm}$ ): $80 \mathrm{~K}$-acetate, $30 \mathrm{KCl}, 40 \mathrm{HEPES}, 3 \mathrm{MgCl}_{2}, 3 \mathrm{EGTA}$, and $1 \mathrm{CaCl}_{2}, \mathrm{pH}$ 7.4. For recording from excised inside-out patches containing KCNQ2/3 channels, the extracellular solution (with $2.5 \mathrm{~mm} \mathrm{~K}^{+}$) was placed in the pipette, and the intracellular solution (with $110 \mathrm{mM} \mathrm{K}^{+}$) was placed in the recording dish. Both faces of the excised patches thus were exposed to "physiological" solutions. Holding potential was $0 \mathrm{mV}$; because $E_{\mathrm{K}}$ was $-95 \mathrm{mV}$, the driving force was $95 \mathrm{mV}$. Movement of $\mathrm{K}^{+}$ions through KCNQ2/3 channels in these patches results in current flow toward the pipette, and this is displayed as downward deflections on recordings.

The $K_{\text {ATP }}$ channel Kir6.2 subunit clone from mouse was generously provided by Dr. S. Seino (Graduate School of Medicine, Chiba University, Japan), and the SUR1 subunit clone from hamster was generously provided by Drs. L. Aguilar Bryan and J. Bryan (Baylor College of Medicine, Houston, TX). Clones were inserted into the mammalian expression vector pCNDA3. $\mathrm{K}_{\mathrm{ATP}}$ channels were transfected as 1:1 molar ratios of Kir6.2 and SUR1 into tsA-201 cells with the green fluorescent protein plasmid in an analogous manner to KCNQ2/3 channels. $\mathrm{K}_{\text {ATP }}$ channels were recorded under symmetrical $\mathrm{K}^{+}$conditions with a pipette solution and superfusion system containing (in mM): $110 \mathrm{KCl}, 30 \mathrm{KOH}, 5$ HEPES, $1 \mathrm{MgCl}_{2}$, and 10 EGTA, pH 7.4, in an inside-out patch configuration. Membrane patches were held at $-60 \mathrm{mV}$, and their cytoplasmic faces were exposed directly to test Mg-ATP solutions via a multi-input perfusion pipette (time to change solution at the tip of the recording pipette was $<2 \mathrm{sec}$ ). All experiments were performed at room temperature $\left(20-22^{\circ} \mathrm{C}\right)$.

Drugs and chemicals. Drugs were applied to BFSG neurons by using a rapid superfusion system that was constructed from 0.8 -mm-diameter polyimide tubes (for details, see Stemkowski et al., 2002). Aliquots of U73122, U73343, or R59022 were dissolved first in chloroform, which then was allowed to evaporate under a stream of nitrogen to yield a filmy residue. This was stored at $-20^{\circ} \mathrm{C}$ until the day of the experiment when it was dissolved in fresh DMSO. LY294002, ML-7, and wortmannin also were dissolved in fresh DMSO. Serial dilutions of drugs in external solution were arranged so that the final concentration of DMSO in solutions applied to cells was $<0.1 \%$. Acute application of $0.1 \%$ DMSO had no noticeable effect on their electrophysiological properties (Table 1). $\mathrm{PIP}_{2}$ was dissolved in chloroform, and aliquots were stored at $-20^{\circ} \mathrm{C}$ under $\mathrm{N}_{2}$. On the day of the experiment the chloroform was evaporated with a stream of $\mathrm{N}_{2}$ to leave a filmy residue of $\mathrm{PIP}_{2}$. Recording solution was mixed with this residue for $\sim 10 \mathrm{~min}$ before sonication on ice until the solution was clear $(\sim 30 \mathrm{~min}) . \mathrm{PIP}_{2}$ antibody was provided as a 1:25 dilution of immune serum. This was dissolved 1:4 in internal solution to achieve a final dilution of 1:100. For control experiments the horse serum was dissolved 1:4 in internal solution. Solutions, especially those containing $\mathrm{AlCl}_{3}$, were made in HPLC water to avoid the formation of $\mathrm{AlF}_{4}^{-}$. 


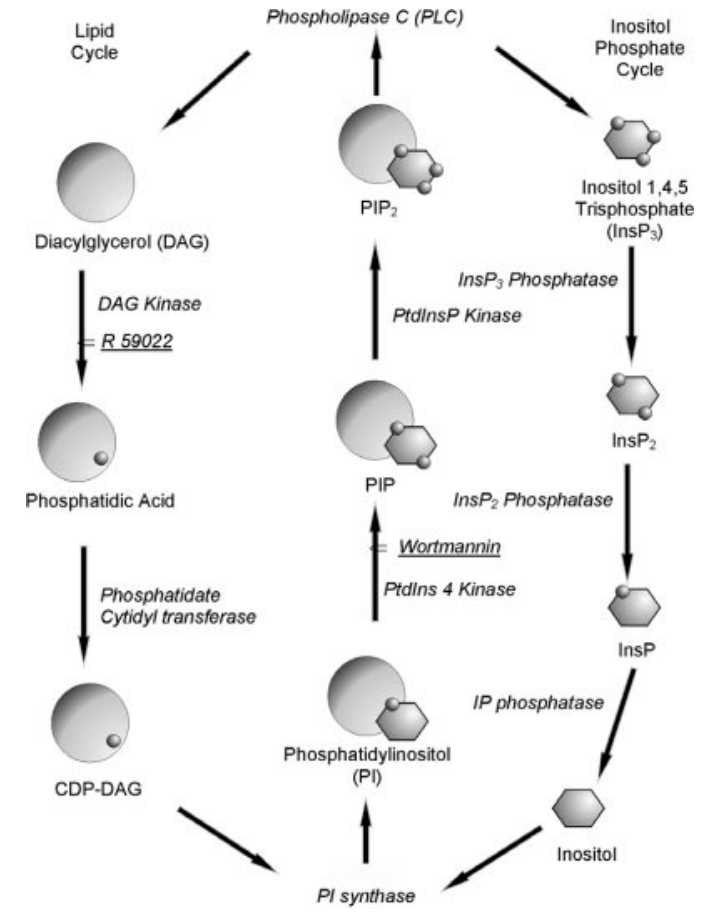

Figure 1. Diagram of the lipid and inositol phosphate cycles. Large circles represent diacylglycerol, small circles represent inorganic phosphate groups, and hexagons represent inositol.

U73122, U73343, ML-7, R59022, and wortmannin were obtained from Biomol (Plymouth Meeting, PA), PIP 2 ( $\alpha$-phosphatidyl-D-myoinositol-4,5-bisphosphate, triammonium salt from bovine brain) was from Calbiochem (San Diego, CA), LY294002 was from Alomone (Jerusalem, Israel), and PIP $_{2}$ antiserum was from Assay Designs (Ann Arbor, MI). All other chemicals were obtained from Sigma (Oakville, Ontario, Canada). Data are expressed as the mean \pm SEM; significance of difference was estimated by using Student's two-tailed $t$ test. Paired tests were used for pairs of observations on the same cell, and unpaired tests were used for a comparison of data from groups of cells. Data were considered significantly different when $p<0.05$.

\section{Results}

Inhibition of $\mathrm{PIP}_{2}$ resynthesis slows recovery from

\section{$\mathrm{g}_{\mathrm{M}}$ suppression}

Wortmannin is a nonselective kinase inhibitor that inhibits myosin light chain kinase (Nakanishi et al., 1992) and phosphatidylinositol 3-kinase (PtdIns 3-kinase) (Yano et al., 1993). The latter is involved in the synthesis of phosphatidylinositol 3,4,5trisphosphate $\left(\mathrm{PIP}_{3}\right)$ from $\mathrm{PIP}_{2}$ (Akasu et al., 1993). At relatively high concentrations wortmannin also inhibits phosphatidylinositol 4-kinase (PtdIns 4-kinase) (Willars et al., 1998; Xie et al., 1999). This enzyme plays a pivotal role in the lipid and inositol phosphate cycles because it is involved in the synthesis of phosphatidylinositol 4-phosphate (PIP) from phosphatidyl inositol (PI). PIP is phosphorylated to $\mathrm{PIP}_{2}$ by phosphatidylinositol phosphate kinase (PtdInsP kinase; Fig. 1). If PLC-induced PIP 2 depletion is required for agonist-induced $\mathrm{g}_{\mathrm{M}}$ suppression, the recovery of the response would require $\mathrm{PIP}_{2}$ resynthesis. This recovery should be slowed in the presence of wortmannin because it would impair $\mathrm{PIP}_{2}$ resynthesis by its action on PtdIns 4-kinase (Runnels et al., 2002; Suh and Hille, 2002) and reduction in the steady-state level of PIP. The data illustrated in Figure $2 a$, which are wholecell recordings from a BFSG B-neuron, are consistent with this prediction. The traces in Figure $2 a$, which are chart recordings of steady-state $I_{\mathrm{M}}$ at $-30 \mathrm{mV}$, are interrupted by responses to voltage

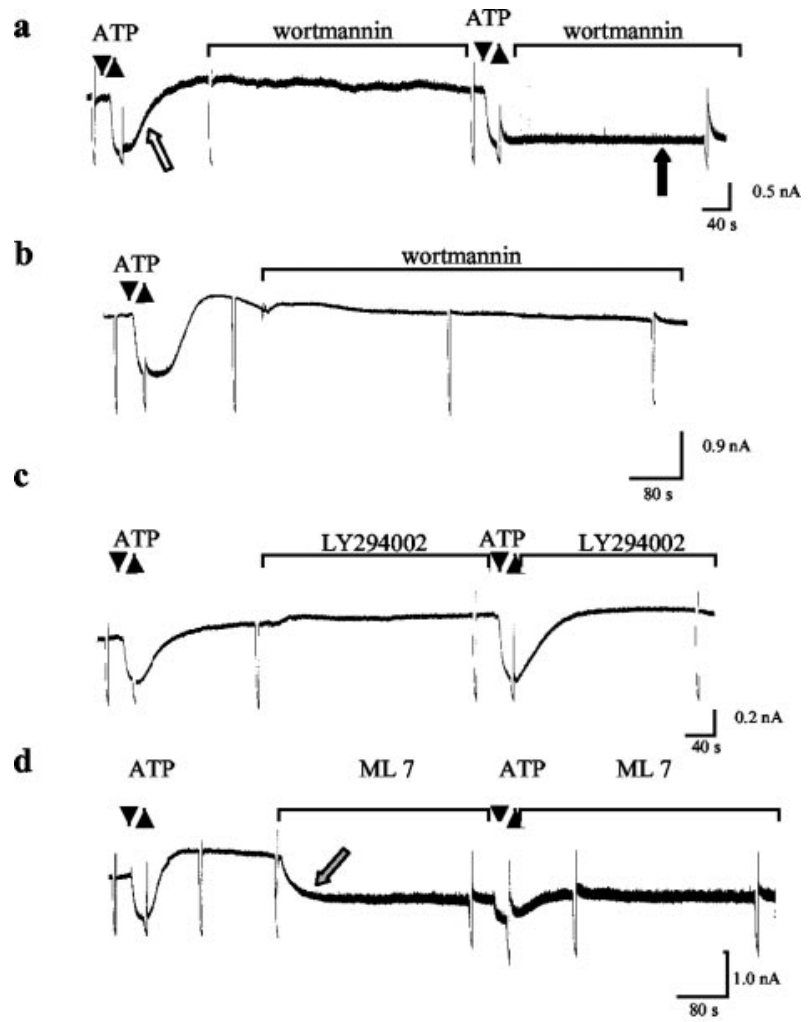

$\mathbf{e}$

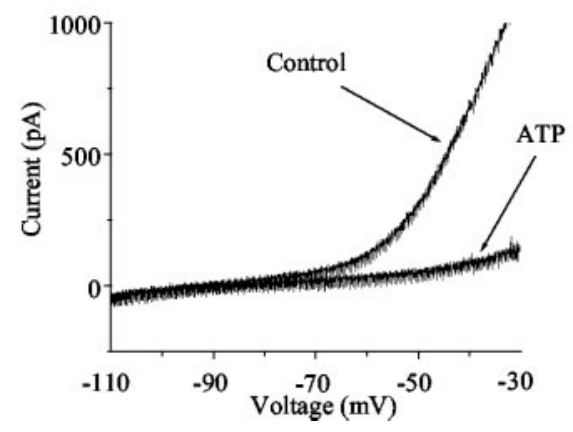

Figure 2. Whole-cell recordings of effects of kinase inhibitors on ATP-induced M-current suppression. Shown are chart recordings of steady-state $I_{M}$ at $-30 \mathrm{mV}$ in BFSG B-neurons (Selyanko et al., 1990). Rapid downward deflections are responses to voltage ramps (from -30 to $-110 \mathrm{mV}$ ) used to assess membrane conductance. Records of voltage commands have been omitted for clarity. $a$, Reversible reduction of $I_{M}$ by $250 \mu \mathrm{M}$ ATP and slowing of recovery of ATP response in the presence of $10 \mu \mathrm{m}$ wortmannin. Arrows indicate recovery phases of ATP responses. $b$, Lack of effect of wortmannin on $I_{M}$ in the absence of ATP application. $c$, Lack of effect of the Ptdlns 3-kinase inhibitor LY294002 (10 $\mu \mathrm{m})$ on ATP responses. $d$, Effect of the myosin light chain kinase inhibitor ML-7 $(10 \mu \mathrm{m})$. This substance produces a rapid attenuation of steady-state $I_{M}$ (gray arrow). Although the amplitude of the ATP response is attenuated, the rate of recovery is unchanged. $e$, Superimposed $I-V$ plots obtained from voltage-ramp commands in $a$ before and during the application of $250 \mu \mathrm{m}$ ATP. Note the decreased conductance at voltages positive to $-70 \mathrm{mV}$ in the presence of ATP, i.e., suppression of conductance in the $g_{M}$ activation range.

ramps that were used to monitor agonist-induced changes in membrane conductance. These ramps produce $I-V$ plots such as those shown in Figure $2 e$ (Selyanko et al., 1990). Before the application of $10 \mu \mathrm{M}$ wortmannin, an extracellular application of $250 \mu \mathrm{M}$ ATP produces pronounced $\mathrm{g}_{\mathrm{M}}$ suppression (Fig. 2a). This is reflected as a reduction in steady-state outward current in the $\mathrm{g}_{\mathrm{M}}$ activation range (positive to $-70 \mathrm{mV}$; Fig. 2 e). Steady-state $I_{\mathrm{M}} / \mathrm{g}_{\mathrm{M}}$ returns to its control value within 1-2 min of initiating ATP washout (Fig. $2 a$, white arrow). After $5 \mathrm{~min}$ in $10 \mu \mathrm{M}$ wort- 
mannin the recovery phase of the ATP response is slowed so that the response is almost irreversible (Fig. 2a, black arrow), and persistent suppression of $g_{M}$ is seen. The time for $50 \%$ recovery of ATP responses increased by $905 \%$, from $19.7 \pm 2.5$ to $198.1 \pm$ $33.5 \sec (n=11 ; p<0.0005)$ in neurons studied with whole-cell recording (Table 1). Similar effects were seen with cells studied with nystatin-perforated patches (Table 1). In these, wortmannin slowed the recovery of ATP responses by $549 \%$, from $21.6 \pm 2.4$ to $118.0 \pm 36.0 \sec (n=9 ; p<0.04)$. Wortmannin also slowed the recovery of responses evoked with $250 \mu \mathrm{M}$ UTP (data not shown). No significant slowing of rate of recovery of successive ATP responses was seen in neurons studied in the absence of wortmannin with the whole-cell or perforated patch methods (Table 1). Figure $2 b$ shows that wortmannin had little effect on steady-state $g_{M} / I_{M}$ when it was applied alone for the 10 min time period of the experiment. Wortmannin thus produces an “agonist-dependent" block of $\mathrm{g}_{\mathrm{M}}$.

If the effect of wortmannin reflected an action of PtdIns 3-kinase rather than PtdIns 4-kinase, a PtdIns 3-kinase inhibitor, such as LY294002, should affect ATP responses in a similar manner to wortmannin. This was not the case. Although LY294002 $(10 \mu \mathrm{M})$ slightly slowed the recovery of ATP responses that were studied with whole-cell recording, this effect was not significant when compared with the time-matched control group (Table 1). Moreover, no slowing of recovery of ATP responses was seen when the effects of LY294002 were studied by the use of perforated patches (Table 1). LY294002 thus did not produce an agonist-dependent block of steadystate $g_{M}$ (Fig. 2c). LY294002 did not affect the time course of recovery of responses evoked with UTP $(250 \mu \mathrm{M}$; data not shown).

Wortmannin was still capable of slowing the recovery of ATP responses in the presence of LY294002. The time for 50\% recovery of ATP responses recorded after $10 \mathrm{~min}$ in $10 \mu \mathrm{M}$ LY294002 was $23.25 \pm 4.3 \mathrm{sec}(n=4)$. After a further $5 \mathrm{~min}$ in $10 \mu \mathrm{M}$ wortmannin plus $10 \mu \mathrm{M}$ LY294002 this increased to $201.3 \pm 62.0$ $(n=4 ; p<0.03)$. This effect of wortmannin cannot be attributed to the inhibition of PtdIns 3-kinase because it persisted after this enzyme was inhibited with LY294002.

To show that the effect of wortmannin did not reflect its action on myosin light chain kinase, we tested whether the inhibitor ML-7 would slow the recovery of ATP responses in a similar manner to wortmannin. ML-7 $(10 \mu \mathrm{M})$ produced a rapidly developing and rapidly reversible reduction in $g_{M}$ that was associated with an increase in membrane noise (Fig. $2 d$, gray arrow). Although this is suggestive of a channel block mechanism, the effect of ML-7 on $g_{M}$ did not exhibit any obvious voltage or use dependence (our unpublished observations). It therefore may reflect a bona fide action on myosin light chain kinase, an enzyme that has been reported to affect $\mathrm{g}_{\mathrm{M}}$ (Akasu et al., 1993; Tokimasa et al., 1995). Despite this, ATP still suppressed the $g_{M}$ that persisted in the presence of ML-7; more importantly, the time course of recovery of the response was changed little (Fig. $2 d$, Table 1). The pronounced slowing of recovery seen with wortmannin (Fig. $2 a)$ thus cannot be attributed to an action on myosin light chain kinase.

The $I-V$ plot shown in Figure $2 e$ is derived from current responses to the voltage ramps shown in Figure $2 a$. This shows that the effect of the extracellularly applied P2Y agonist ATP is confined to the $\mathrm{g}_{\mathrm{M}}$ activation range. The absence of any conductance change at potentials more negative than $-70 \mathrm{mV}$ excludes the participation of $\mathrm{P} 2 \mathrm{X}$ receptors in the response to ATP. a

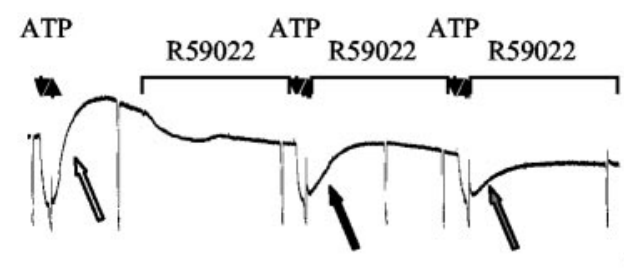

b

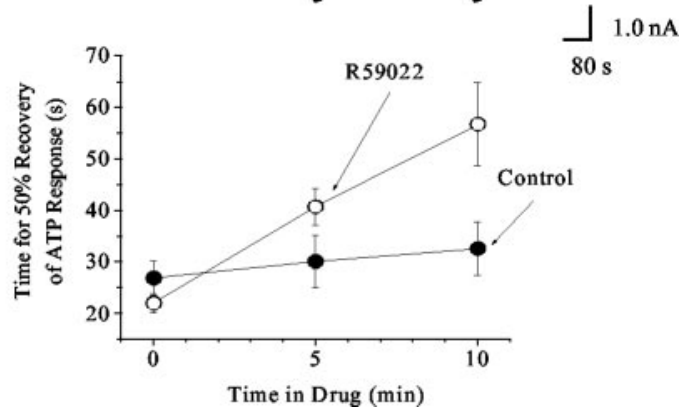

Figure 3. Whole-cell recordings of effects of the diacylglycerol kinase inhibitor R59022 on ATP-induced M-current suppression. $a$, Chart recordings of steady-state $I_{M}$ at $-30 \mathrm{mV}$ in BFSG B-neurons (Selyanko et al., 1990). Rapid downward deflections are responses to voltage ramps (from -30 to $-110 \mathrm{mV}$ ) used to assess membrane conductance. Records of voltage commands have been omitted for clarity. Response to $250 \mu \mathrm{M}$ ATP applied before R59022 shows rapid recovery, but rate of recovery progressively decreases during superfusion of $10 \mu \mathrm{M}$ R59022. Arrows indicate recovery phases of ATP responses. $b$, Summary of data from all of the cells that were tested. Times for $50 \%$ recovery of ATP responses were recorded before and after 5 and 10 $\mathrm{min}$ in R59022. Note the progressive slowing of recovery of ATP responses recorded in the presence of R59022 as compared with controls recorded without drug. Error bars indicate \pm $\mathrm{SEM} ; n$ ranges from 6-9 measurements for each point.

\section{Inhibition of the lipid cycle slows recovery from $\mathrm{g}_{\mathrm{M}}$ suppression}

The above observations on ATP responses are similar to those of Suh and Hille (2002), who suggested that resynthesis of $\mathrm{PIP}_{2}$ is required for the recovery of muscarine-induced $g_{M}$ suppression in rat superior cervical ganglion neurons and for the recovery of muscarinic suppression of KCNQ2/3 channel currents expressed in tsA-201 cells. If this is so, depletion of PI, which is the substrate for PtdIns 4-kinase (Fig. 1), also would be expected to slow $g_{M}$ recovery. This is because, by classical enzyme kinetics, the rate of synthesis of phosphatidylinositol phosphates by PtdIns 4-kinase will depend on the concentration of the substrate, PI. We therefore interrupted the lipid cycle after diacylglycerol (DAG) by using the DAG kinase inhibitor R59022 (40 $\mu \mathrm{M})$. A typical experiment is illustrated in Figure $3 a$. The initial 5 min exposure to R59022 had little effect on the rate of recovery of the ATP response. However, a second test of ATP in the continued presence of R59022 produced a response with slowed recovery. This trend (progressive slowing of recovery of successive ATP responses in the continued presence of R59022) is apparent in the summarized data for all of the cells that were tested (Fig. $3 b$ ). Very little slowing of the recovery of successive ATP responses was seen in control neurons. Thus the time for $50 \%$ recovery of the ATP response in untreated neurons was $32.6 \pm 5.1$ $\sec (n=8)$, and this was significantly less than the $56.7 \pm 8.1 \mathrm{sec}(n=$ 6) seen in neurons after $10 \mathrm{~min}$ in $40 \mu \mathrm{M}$ R59022 ( $p<0.025)$. We suggest that, after one test of ATP in the presence of R59022, the membrane concentrations of PI and PIP are still sufficient to sustain the normal rate of resynthesis of $\mathrm{PIP}_{2}$ via PtdIns 4-kinase and PtdInsP kinase (Fig. 1). M-channels thus reopen at the control rate. With the second application of ATP, however, PI and PIP may be depleted irreversibly because their resynthesis has been interrupted by the R59022 inhibition of DAG kinase (Fig. 1). The corresponding 
a $\mathrm{PIP}_{2}$ Antibody

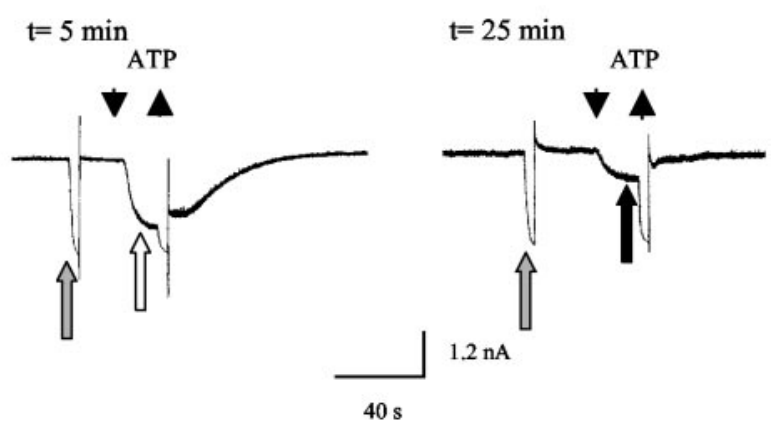

b Serum Control

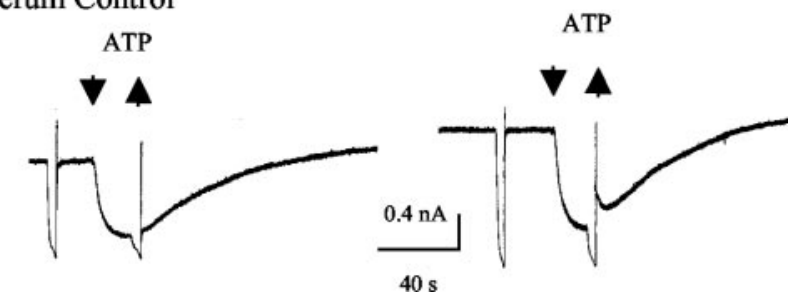

Figure 4. Whole-cell recordings illustrate the effect of $\mathrm{PIP}_{2}$ antibody on ATP-induced M-current suppression. Shown are chart recordings of steady-state $I_{M}$ at $-30 \mathrm{mV}$ in BFSG B-neurons (Selyanko et al., 1990). Rapid downward deflections are responses to voltage ramps (from -30 to $-110 \mathrm{mV}$ ) used to assess membrane conductance. Records of voltage commands have been omitted for clarity. $a$, Responses to $250 \mu \mathrm{m}$ ATP recorded with a pipette containing 1:100 $\mathrm{PIP}_{2}$ antibody. Left, Response recorded $5 \mathrm{~min}$ after whole-cell recording conditions were established. Right, Response recorded after $25 \mathrm{~min}$ of recording. Note the preservation of steady-state $I_{M}$ as demonstrated by the unchanged amplitude of current responses to voltage ramps (gray arrows) but decreased effectiveness of ATP as demonstrated by smaller amplitude response (black arrows compared with white arrows). $b$, Effect of recording via a pipette containing horse serum (1:4 in internal solution) as a control experiment for the data presented in a. Because the antibody concentration was $1: 25$ in serum protein, the internal solution was replaced 1:4 by horse serum to obtain 1:100 control protein solution.

rate of $g_{M}$ recovery thus is reduced. These findings are consistent with a role for $\mathrm{PIP}_{2}$ resynthesis in $\mathrm{g}_{\mathrm{M}}$ recovery (Suh and Hille, 2002) and further implicate earlier intermediates of the lipid cycle as the source of phosphatidic acid for this effect (Fig. 1).

\section{PIP $_{2}$ antibodies attenuate ATP-induced $\mathrm{g}_{\mathrm{M}}$ suppression}

Studies of $\mathrm{PIP}_{2}$ modulation of other types of $\mathrm{K}^{+}$channels (Huang et al., 1998; Xie et al., 1999; Leung et al., 2000; Bian et al., 2001) have led to the development of well characterized $\mathrm{PIP}_{2^{-}}$ neutralizing antibodies that reduce $\mathrm{PIP}_{2}$-dependent channel activity in a variety of cell types (Huang et al., 1998; Liou et al., 1999; Bian et al., 2001; Chuang et al., 2001). Under the conditions of our experiments, however, inclusion of $\mathrm{PIP}_{2}$-neutralizing antiserum $(100: 1)$ in the patch pipette failed to affect resting $g_{M}$ in BFSG neurons. Despite this, the modulation of $\mathrm{g}_{\mathrm{M}}$ by ATP was disrupted consistently. Thus after 5 min of recording with antibody in the pipette, $250 \mu \mathrm{M}$ ATP suppressed $g_{M}$ by $85.6 \pm 3.1 \%$, but after $25 \mathrm{~min}$ of recording the agonist effectiveness was reduced so that only $42.9 \pm 15.2 \%$ suppression was seen $(n=4 ; p=$ 0.05 , paired $t$ test). A typical experiment is illustrated in Figure $4 a$. The steady state- $\mathrm{g}_{\mathrm{M}}$ was little changed by the antibody (Fig. $4 a$, gray arrows), whereas the amount of ATP-induced $g_{M}$ suppression was far greater for the first response (Fig. $4 a$, white arrow) than for the second response (Fig. $4 a$, black arrow). The effect of antiserum was not seen in control experiments in which an appropriate amount of horse serum was included in the recording pipette (Fig. $4 b$ ). Thus ATP suppressed $g_{M}$ by $83.4 \pm 8.0 \%$ after 5 min with the intracellular horse serum and by $76.1 \pm 7.9 \%$ after $25 \min (n=5 ; p>0.5)$. One interpretation of these findings is that the antibody preferentially inhibits the $\mathrm{PIP}_{2}-\mathrm{PLC}$ interaction rather than a $\mathrm{PIP}_{2}-\mathrm{M}$-channel interaction.

\section{Direct effects of $\mathrm{PIP}_{2}$ on KCNQ2/3 channels}

If $\mathrm{M}$-channel closure is promoted by the PLC-mediated hydrolysis of PIP 2 (Suh and Hille, 2002), steady-state $\mathrm{g}_{\mathrm{M}}$ should be increased in the presence of exogenously applied $\mathrm{PIP}_{2}$ (Ikeda and Kammermeier, 2002). One recent report suggests that exogenously applied $\mathrm{PIP}_{2}$ increases putative $\mathrm{M}$-current activity in cellattached excised patches from rat sympathetic neurons (Zhang et al., 2003). This seemingly simple experiment is remarkably difficult to perform. One issue may be the simple physical problem of taking a hydrophobic lipid, such as $\mathrm{PIP}_{2}$, and delivering to the cell membrane via the aqueous environment of the recording solutions. We therefore first sought to verify the effectiveness of our aqueous solutions of $\mathrm{PIP}_{2}$.

Because $\mathrm{PIP}_{2}$ is known to decrease the sensitivity of $\mathrm{K}_{\mathrm{ATP}}$ channels to blockade by intracellular ATP (Fan and Makielski, 1997; Baukrowitz et al., 1998), we used this effect to confirm the activity of our $\mathrm{PIP}_{2}$ solutions. $\mathrm{K}_{\mathrm{ATP}}$ channels were expressed in tsA-201 cells, and $\mathrm{PIP}_{2}$ was included in the recording pipette on the extracellular side of excised inside-out patches (Fig. $5 a$, inset). $\mathrm{PIP}_{2}$ is able to reach the cytosolic face to modulate $\mathrm{K}_{\mathrm{ATP}}$ channels when it is applied to the extracellular face (Wada et al., 2002). After 5 min the control channels displayed similar ATP sensitivity to that initially recorded ( $n=2$; Fig. $5 a$ ). Channels exposed to $\mathrm{PIP}_{2}(20 \mu \mathrm{M})$ exhibited a marked reduction in sensitivity to intracellular ATP, because substantially greater current was available at $0.1 \mathrm{~mm}$ ATP and even at $1 \mathrm{~mm}$ (a concentration that fully inhibited control channels; $n=2$; Fig. $5 b$ ).

Because a majority of the studies demonstrating the effects of $\mathrm{PIP}_{2}$ on $\mathrm{K}^{+}$channels have been performed on expressed (Huang et al., 1998; Zhang et al., 1999; Leung et al., 2000; Bian et al., 2001) rather than on native channels, we next used whole-cell recording to examine the effect of $\mathrm{PIP}_{2}$ on KCNQ2/3 channels expressed in tsA-201 or COS-1 cells (Wang et al., 1998). In cells in which the channels were transfected successfully, voltage commands from -20 to $-50 \mathrm{mV}$ produced a classical $\mathrm{g}_{\mathrm{M}}$ relaxation (Brown and Adams, 1980) in response to the start of the voltage pulse and reactivation of the conductance when the membrane voltage was restored to $-20 \mathrm{mV}$ (Fig. $5 c$, inset). Under the conditions of our experiments KCNQ2/3 channel currents in tsA-201 or COS-1 cells displayed significant rundown during the initial $5 \mathrm{~min}$ of recording with ATP-free internal solution in the pipette. The presence of ATP in the intracellular pipette or metabolic substrates such as pyruvate or glucose in the extracellular solution are known to slow the rate of rundown of M-channels during wholecell recording (Pfaffinger et al., 1988; Simmons and Schneider, 1998; Suh and Hille, 2002). This suggests that ATP may be required for lipid kinase activity (i.e., PtdIns 4-kinase, PtdInsP kinase) and thus for the maintenance of $\mathrm{PIP}_{2}$ levels in the membrane (Suh and Hille, 2002). If $\mathrm{PIP}_{2}$ is required to maintain $\mathrm{M}$-channel function, application of this lipid via the patch pipette therefore would be expected to slow rundown. Figure $5 c$ compares the time course of change of KCNQ2/3 channel current, measured from tail currents at $-50 \mathrm{mV}$, in 16 control cells with that in 11 cells recorded with $20 \mu \mathrm{M} \mathrm{PIP}$ in the recording pipette. The current amplitude decreased to $45.2 \pm 8.8 \%$ of the initial $(n=16)$ after 3 min of recording. In contrast, KCNQ2/3 channel current recorded with $20 \mu \mathrm{M} \mathrm{PIP}_{2}$ in the recording pipette decreased significantly less, to $83.3 \pm 16.6 \%$ of the initial $(n=11$; 
a

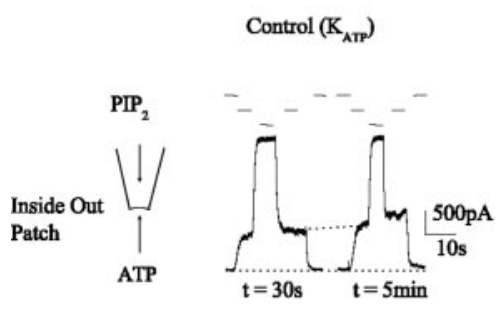

b

$20 \mu \mathrm{M} \operatorname{PIP}_{2}\left(\mathrm{~K}_{\text {ATP }}\right)$

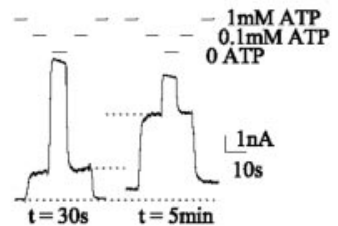

d e

$20 \mu \mathrm{M} \mathrm{PIP}_{2}(\mathrm{KCNQ} 2 / 3)$
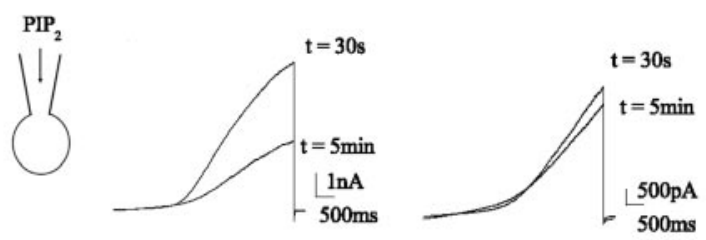

c $\mathrm{KCNQ} 2 / 3$

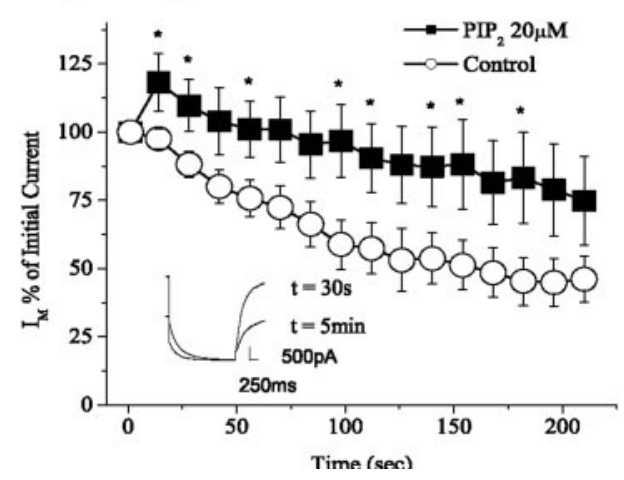

f

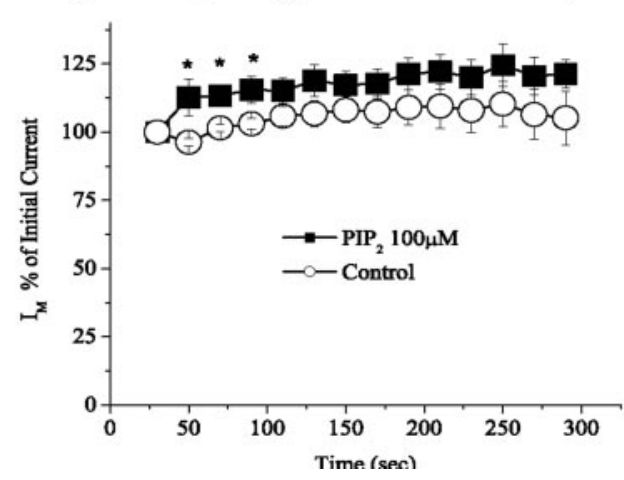

$\mathrm{PIP}_{2}$

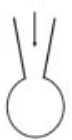

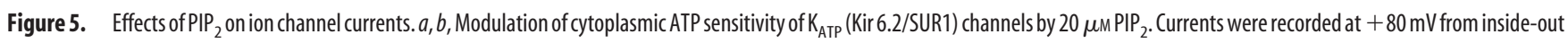
patches at 30 sec and 5 min after patches were pulled from tsA-201 cells (see inset for diagram of recording arrangement). Note the lack of altered ATP sensitivity of currents recorded with a control pipette after $5 \mathrm{~min}(a)$ as opposed to the reduced sensitivity to the inhibitory effects of ATP of currents recorded with a pipette containing $20 \mu \mathrm{M}$ PIP 2 ( $b$; see inset for diagram of recording arrangement). $(-e$, Whole-cell recordings from tsA-201 cells. c, Comparison of the time course of rundown of KCNQ2/3 currents in control tsA-201 or COS cells ( $n=21$ ) as compared with cells studied with a pipette containing $20 \mu \mathrm{MPIP}$ ( $n=10 ; p<0.05$ for points labeled with an asterisk). Inset, Relaxation and reactivation of KCNQ2/3 channel currents in response to a voltage step from -20 to $-50 \mathrm{mV}$. Currents were recorded $30 \mathrm{sec}$ and $5 \mathrm{~min}$ after whole-cell recording was initiated. $d, e$, Responses to ramp commands from -80 to $+50 \mathrm{mV}$ to show current-voltage characteristics of KCNQ2/3 channels over a broad voltage range. Currents were recorded $30 \mathrm{sec}$ and $5 \mathrm{~min}$ after whole-cell recording was initiated. Note the rundown of current in the cell illustrated in $d$ and the persistence of current in the cell illustrated in e, which was studied with a pipette that contained $20 \mu \mathrm{M} \mathrm{PIP}_{2}$ (see inset for diagram of recording arrangement). $f$, Whole-cell recordings from BFSG C-neurons. Shown is a comparison of the first 5 min of recordings of $I_{M}$ in control BFSC C-neurons (ATP-free intracellular solution; $n=9$ ) as compared with cells studied with a pipette containing 100 $\mu \mathrm{M} \mathrm{PIP}_{2}$ ( $n=11 ; p<0.05$ for points labeled with an asterisk).

$p<0.05)$. In other experiments the $I-V$ characteristics of expressed $\mathrm{KCNQ} 2 / 3$ channels were studied over a wide range by using $4.75 \mathrm{sec}$ commands from -80 to $+50 \mathrm{mV}$. In these experiments the current recorded at $+50 \mathrm{mV}$ decreased to $58.6 \pm 6.2 \%$ of control $(n=27)$ after $5 \mathrm{~min}$ with normal intracellular solution. Inclusion of $20 \mu \mathrm{M}$ $\mathrm{PIP}_{2}$ in the pipette significantly reduced rundown of these currents such that those recorded after 5 min were still $85.1 \pm 10.8 \%$ of control $(n=12 ; p<0.05)$. Typical experiments are illustrated in Figure $5, d$ and $e$. Thus $20 \mu \mathrm{M} \mathrm{PIP}_{2}$ is able to modulate KCNQ2/3 channels expressed in tsA-201 or COS-1 cells. This concentration was chosen because it is within the $8-50 \mu \mathrm{M}$ range of concentrations used in other investigations of phospholipid modulation of ion channels in other systems (Zhang et al., 1999; Bian et al., 2001; Runnels et al., 2002; Rohacs et al., 2003).

\section{Effect of $\mathrm{PIP}_{2}$ on M-currents in BFSG cells}

To study the effect of $\mathrm{PIP}_{2}$ on native neurons, we examined its effect on the smaller C-cells of BFSG that express an agonistsensitive $g_{M}$ (Jones, 1987) similar to that of the larger B-cells that were used above. We postulated that the smaller volume of the C-cell cytoplasm (Dodd and Horn, 1983; Kurenny et al., 1994) would favor the partition of $\mathrm{PIP}_{2}$ into their membranes. As with the experiments on KCNQ2/3 channels in COS-1 or tsA-201 cells, ATP was excluded from the intracellular solution when $\mathrm{PIP}_{2}$ was tested on BFSG neurons. Although $20 \mu \mathrm{M} \mathrm{PIP}_{2}$ slowed the rundown of KCNQ2/3 currents, this concentration failed to affect $g_{M}$ in BFSG C-cells. Table 2 shows that there was no signifi-
Table 2. Effect of PIP ${ }_{2}$ on $g_{M}$ in BFSG C-cells

\begin{tabular}{llc}
\hline & Initial $I_{\mathrm{M}}$ at $30 \sec (\mathrm{pA})$ & $I_{\mathrm{M}}$ at $4 \mathrm{~min}(\mathrm{pA})$ \\
\hline ATP-free internal $(n=7)$ & $621.5 \pm 77.3$ & $519.7 \pm 91.4$ (n.s.) \\
ATP-free internal $+\mathrm{PIP}_{2}$ & $824.4 \pm 242.2$ & $721.6 \pm 233.4$ (n.s.) \\
$\quad(20 \mu \mathrm{M} ; n=5)$ & & (n.s. vs ATP-free) \\
ATP-free internal $(n=9)$ & $817.3 \pm 89.0$ & $864.4 \pm 92.2$ (n.s.) \\
ATP-free internal + PIP & $734.2 \pm 130.8$ & $882.9 \pm 162.3(p<0.02)$ \\
$\quad(100 \mu \mathrm{m} ; n=11)$ & & (n.s. vs ATP-free) \\
\hline
\end{tabular}

Paired $t$ tests were used to compare current amplitudes at 30 sec and 4 min in each cell studied. Unpaired $t$ tests were used to compare differences between groups of cells after 4 min of recording under various experimental conditions. Whole-cell recordings were used in all cases. n.s., Not significant.

cant change in $\mathrm{g}_{\mathrm{M}}$ in these cells between $30 \mathrm{sec}$ and $4 \mathrm{~min}$ of recording either with or without $20 \mu \mathrm{M} \mathrm{PIP}_{2}$ in the recording pipette (Student's paired $t$ test). Moreover, there was no significant difference in the amount of $g_{M}$ in the two groups of cells after 4 min of recording (Student's unpaired $t$ test).

In contrast, the amplitude of $\mathrm{g}_{\mathrm{M}}$ recorded after the intracellular application of a high concentration of $\mathrm{PIP}_{2}(100 \mu \mathrm{M})$ was significantly larger after 4 min of recording than after $30 \mathrm{sec}$ of recording ( $p<0.02$, using Student's paired $t$ tests on data from each cell to compare current values at $30 \mathrm{sec}$ and $4 \mathrm{~min}$; Table 2). This effect of $\mathrm{PIP}_{2}$ is rather modest because there was no significant difference in the amount of $g_{M}$ in control cell population as compared with the $100 \mu \mathrm{M} \mathrm{PIP}_{2}$-treated population after 4 min of recording (Student's unpaired $t$ test was used to compare all control current values, with all values measured in the presence of 
Table 3. Effects of $\mathrm{PIP}_{2}$ on $\mathrm{g}_{\mathrm{M}}$ in BFSG C-neurons after inhibition of $\mathrm{PIP}_{2}$ metabolism

\begin{tabular}{|c|c|c|c|}
\hline & Initial $I_{\mathrm{M}}$ at $30 \mathrm{sec}(\mathrm{pA})$ & Final $I_{M}$ at $5 \min (\mathrm{pA})$ & Change (\%) \\
\hline ATP-free internal $(n=7) \dagger$ & $621.5 \pm 77.3$ & $519.7 \pm 91.4$ (n.s.) & -16.3 \\
\hline ATP-free internal $+\mathrm{PIP}_{2}(20 \mu \mathrm{m} ; n=5) \dagger$ & $824.4 \pm 242.2$ & $721.6 \pm 233.4$ (n.s.) (n.s. vs ATP-free) & -12.4 \\
\hline $\operatorname{FVPP}(n=12) \dagger$ & $1083.4 \pm 227.7$ & $976.2 \pm 183.4$ (n.s.) & -9.9 \\
\hline $\mathrm{FVPP}+\mathrm{PIP}_{2}(20 \mu \mathrm{m} ; n=13) \dagger$ & $1129.9 \pm 166.5$ & $984 \pm 163.2$ (n.s.) (n.s. vs PVFF) & -12.9 \\
\hline Wortmannin $(10 \mu \mathrm{m} ; n=5)$ & $373.4 \pm 114.4$ & $306.4 \pm 106.4^{*}$ (n.s.) & -17.9 \\
\hline Wortmannin $(10 \mu \mathrm{M})+\mathrm{PIP}_{2}(20 \mu \mathrm{m} ; n=6)$ & $675.2 \pm 182.8$ & $658.3 \pm 204^{*}$ (n.s.) (n.s. vs wortmannin) & -2.5 \\
\hline $\mathrm{U} 73122(10 \mu \mathrm{m} ; n=8)$ & $385.9 \pm 88.2$ & $277.3 \pm 64.1^{* *}($ n.s. $)$ & -28.1 \\
\hline $\mathrm{U} 73122(10 \mu \mathrm{M})+\mathrm{PIP}_{2}(20 \mu \mathrm{m} ; n=11)$ & $292.4 \pm 83.9$ & $284.2 \pm 88.7^{* *}$ (n.s.) (n.s. vs U73122) & -2.8 \\
\hline
\end{tabular}

Paired $t$ tests were used to compare current amplitudes at 30 sec and 4 min in each cell studied. Unpaired $t$ tests were used to compare differences between groups of cells after 4 min of recording under various experimental conditions. Whole-cell recordings were used in all cases. *Final $I_{\mathrm{M}}$ measured at $t=3.5 \mathrm{~min} ;{ }^{* *}$ final $I_{\mathrm{M}}$ measured at $t=4 \mathrm{~min} ; 2 \mathrm{mM}$ ATP was included in the intracellular solution unless otherwise indicated by $t$. n.s., Not significant.

$\mathrm{PIP}_{2}$ at 4 min; Table 2). Figure $5 f$ compares the recorded values of $\mathrm{g}_{\mathrm{M}}$ over the first $5 \mathrm{~min}$ of recording in cells with and without 100 $\mu \mathrm{M} \mathrm{PIP}_{2}$. Although significant differences are seen at early time intervals, the effect of $\mathrm{PIP}_{2}$ on $\mathrm{g}_{\mathrm{M}}$ in BFSG is very small when compared with its effect on KCNQ2/3 channels (Fig. $5 c$ ).

Intracellular application of $100 \mu \mathrm{M} \mathrm{PIP}$ also did not interfere with the ability of $\mathrm{P} 2 \mathrm{Y}$ agonists to suppress $\mathrm{g}_{\mathrm{M}}$. Thus extracellular application of $250 \mu \mathrm{M}$ ATP suppressed $\mathrm{g}_{\mathrm{M}}$ by $66.9 \pm 6.2 \%(n=$ 11) in $\mathrm{PIP}_{2}$-treated cells, and this was no different from the amount of suppression seen in control cells $61.5 \pm 9.2 \%(n=9$; $p>0.6)$. This lack of effect on agonist-induced responses may have reflected our inability to alter $\mathrm{PIP}_{2}$ concentration in the vicinity of the channels; had this occurred, the amplitude of the steady-state current may have been increased more convincingly (Table 2).

\section{Investigation of limited effectiveness of $\mathrm{PIP}_{2}$ on BFSG neurons}

The limited effectiveness of PIP $_{2}$ in BFSG neurons could be attributable to degradation of exogenously applied $\mathrm{PIP}_{2}$ by endogenous lipid phosphatases (Zhang et al., 1999). To test this, we inhibited lipid phosphatases by using an internal solution containing (in $\mathrm{mm}$ ): 5 sodium fluoride, 0.1 sodium orthovanadate, and 10 sodium pyrophosphate (FVPP solution) (Huang et al., 1998). Inclusion of a FVPP solution in the recording pipette, however, did not increase the effectiveness of $\mathrm{PIP}_{2}$ (Table 3 ).

Alternatively, the limited effectiveness of exogenously applied $\mathrm{PIP}_{2}$ may reflect saturation of binding sites on $\mathrm{M}$-channels by endogenous $\mathrm{PIP}_{2}$. In an attempt to deplete endogenous $\mathrm{PIP}_{2}$, we applied (extracellular) ATP to activate $\mathrm{P} 2 \mathrm{Y}$ receptors and to promote PLC-induced $\mathrm{PIP}_{2}$ hydrolysis. This was done in the presence of wortmannin to prevent $\mathrm{PIP}_{2}$ resynthesis before gaining whole-cell access to the cell. Cells were pretreated thus with $10 \mu \mathrm{M}$ wortmannin for $5 \mathrm{~min}$ after which ATP was applied for $20 \mathrm{sec}$. At this time whole-cell access was obtained, and the $I_{\mathrm{M}}$ recorded after $30 \mathrm{sec}$ was compared with that recorded after $4 \mathrm{~min}$. When cells were treated in this manner, the inclusion of $\mathrm{PIP}_{2}(20 \mu \mathrm{M})$ in the recording pipette did not alter $\mathrm{g}_{\mathrm{M}}$ (Table 3 ).

$\mathrm{PIP}_{2}(20 \mu \mathrm{M})$ also was included in the patch pipette after PLC had been inhibited with U73122 (5 min; $10 \mu \mathrm{M})$ to determine whether tonically active PLC was hydrolyzing the applied PIP 2 . Under these conditions, however, $\mathrm{PIP}_{2}$ still failed to increase $\mathrm{g}_{\mathrm{M}}$ (Table 3).

Thus the poor efficacy of exogenously applied $\mathrm{PIP}_{2}$ in modulating $g_{M}$ under the conditions of our experiments is unlikely to reflect the presence of endogenous phosphatases (Huang et al., 1998), saturation of possible binding sites on M-channels by endogenous $\mathrm{PIP}_{2}$, or ongoing catabolism of $\mathrm{PIP}_{2}$ by the action of PLC.

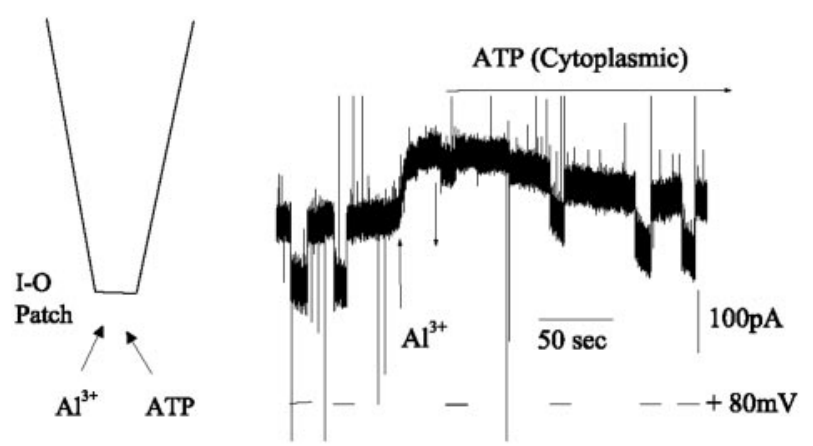

Figure 6. Effects of $\mathrm{Al}^{3+}$ and intracellularly applied ATP on KCNQ2/3 current in excised patches. Shown is a recording of KCNQ2/3 current in an inside-out patch excised from a tsA-201 cell. Pipette solution contained $2.5 \mathrm{~mm} \mathrm{~K}^{+}$, and the solution outside the patch contained 110 $\mathrm{mm} \mathrm{K}^{+} ; E_{\mathrm{K}}=-95 \mathrm{mV}$. Holding potential was $0 \mathrm{mV}$, so current through $\mathrm{KCNQ2} / 3$ channels is toward the pipette (i.e., inward according to usual convention). Bath application of $50 \mu \mathrm{M} \mathrm{AICl}$ (to the cytoplasmic face of the membrane) reduced current by $\sim 100 \mathrm{pA}$, and current was restored in part by the application of $1 \mathrm{~mm}$ ATP (also to the cytoplasmic side of the membrane; see inset for diagram of recording arrangement). Horizontal bars show $+80 \mathrm{mV}$ step changes in holding potential across the patch from $0 \mathrm{mV}$ to increase the driving force and to measure conductance. Note the decrease in conductance in the presence of $\mathrm{Al}^{3+}$ and the restoration of conductance with ATP.

\section{Effects of $\mathrm{Al}^{3+}$}

Because negative charges on the phosphate moieties of phosphatidylinositides are involved in their binding to positively charged residues on $\mathrm{K}^{+}$channels (Zhang et al., 1999), trivalent cations such as $\mathrm{Al}^{3+}$ strongly disrupt $\mathrm{PIP}_{2}$ channel interactions (Hilgemann and Ball, 1996). To test whether $\mathrm{Al}^{3+}$ affected M-channels, we studied KCNQ2/3 channels in inside-out macropatches excised from tsA-201 cells. Apart from leak, almost all current in such patches should be attributable to KCNQ2/3 current. We found that the total current at $0 \mathrm{mV}$ was suppressed by $47.0 \pm 6.7 \%$ by $50 \mu \mathrm{M} \mathrm{Al}^{3+}(n=5)$. In the experiment illustrated in Figure 6, the addition of $1 \mathrm{mM}$ ATP to the intracellular surface of the membrane so as to promote $\mathrm{PIP}_{2}$ synthesis (Suh and Hille, 2002) partly reversed the effect of $\mathrm{Al}^{3+}$.

\section{PIP $_{2}$ and suppression of $\mathrm{g}_{\mathrm{M}}$ by muscarine}

The M-current was defined first as a muscarine-sensitive current in BFSG neurons (Brown and Adams, 1980). Suppression of $g_{M}$ by muscarinic agonists in rat superior cervical ganglion neurons is attenuated by $3 \mu \mathrm{M} \mathrm{U} 73122$, and this had led to the conclusion that PLC likely participates in the transduction mechanism for this agonist in mammalian sympathetic ganglia (Suh and Hille, 2002). Although the PLC inhibitor U73122 (10 $\mu \mathrm{M})$ antagonized the effect of 5-10 $\mu \mathrm{M}$ muscarine on $\mathrm{g}_{\mathrm{M}}$ in BFSG B-neurons (Fig. $7 a$ ), this effect also was seen with the inactive isomer U73343 (Fig. 


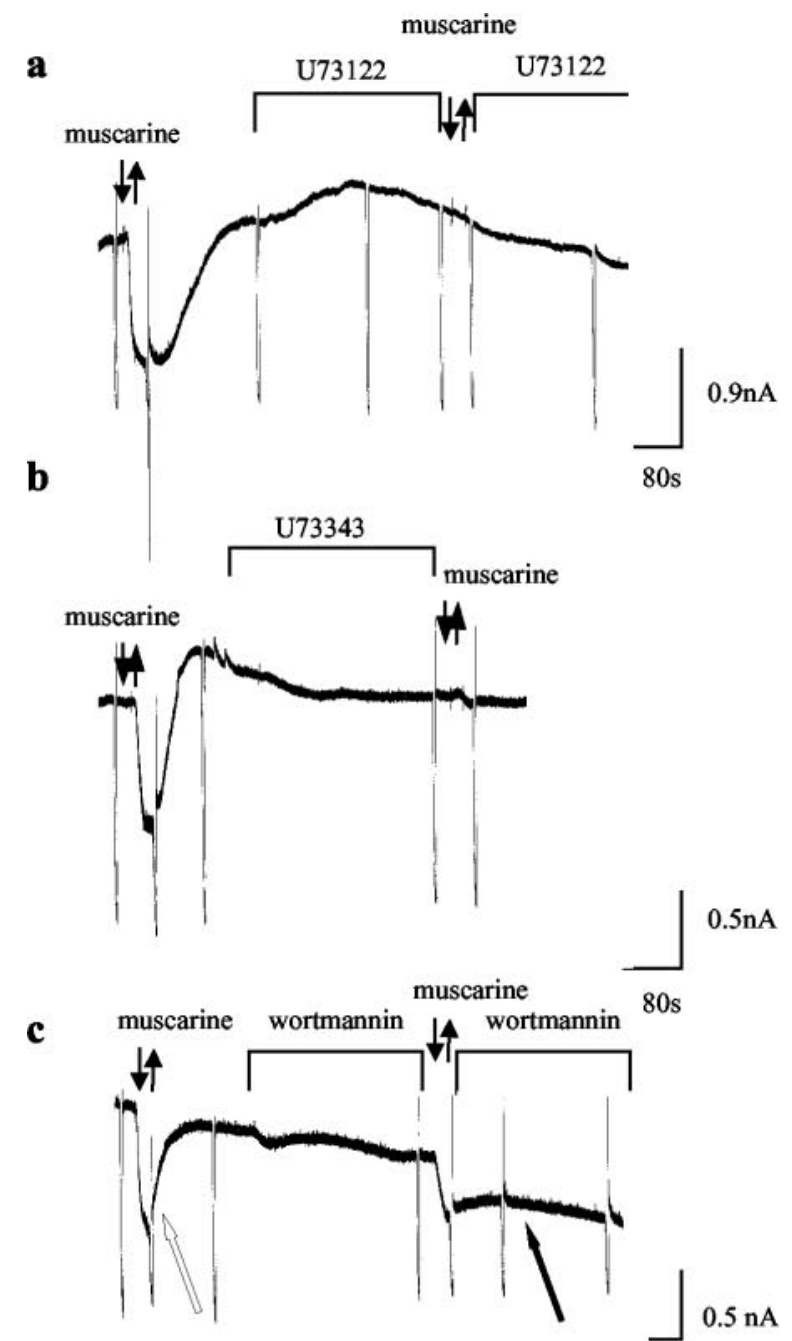

d $\mathrm{PIP}_{2}$ Antibody

$80 \mathrm{~s}$

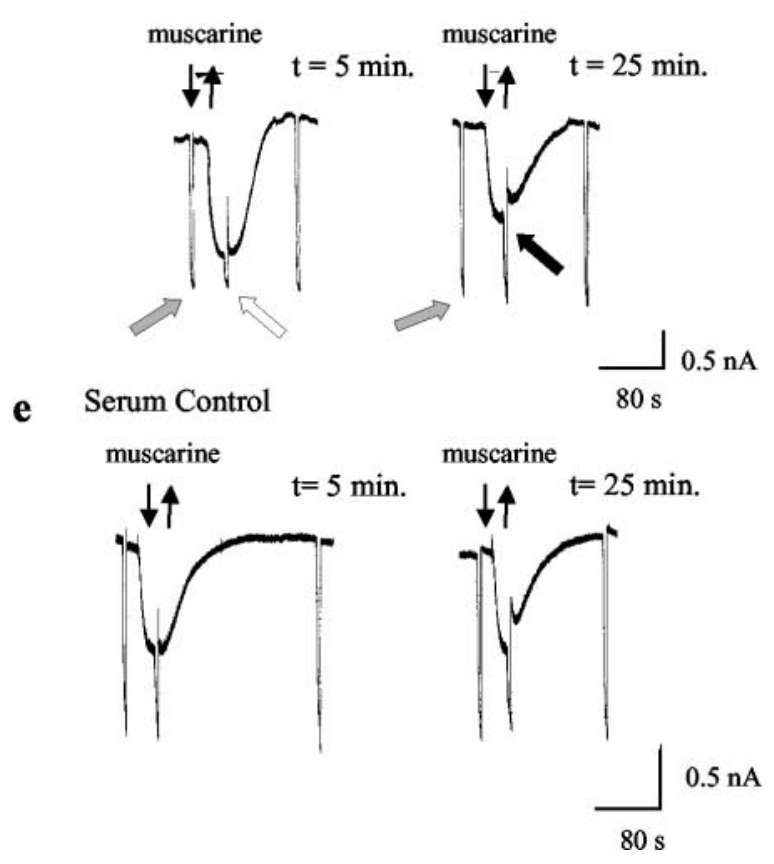

Figure 7. Whole-cell recordings from BFSG neurons illustrate the effects of kinase inhibitors and $\mathrm{PIP}_{2}$ antibodies on muscarine-induced $\mathrm{g}_{\mathrm{M}}$ suppression. Shown are chart recordings of steady-state $I_{M}$ at $-30 \mathrm{mV}$ in BFSG B-neurons (Selyanko et al., 1990). Rapid downward deflec-
Table 4. Effect of PLC-inhibitor U73122 and its inactive isomer U73343 on muscarine responses

\begin{tabular}{|c|c|c|}
\hline & $\begin{array}{l}g_{M} \text { suppression by } \\
10 \mu \mathrm{M} \text { muscarine }\end{array}$ & $\begin{array}{l}g_{M} \text { suppression by } 10 \mu \mathrm{m} \text { muscarine } \\
\text { in presence of inhibitor }\end{array}$ \\
\hline U73122 $(10 \mu \mathrm{M})(n=6)$ & $80.8 \pm 4.2 \%$ & $\begin{array}{l}10.2 \pm 2.8 \%(p<0.0001) \\
13.6 \pm 3.7 \%(p<0.0002) p=0.5\end{array}$ \\
\hline $\operatorname{U} 73343(10 \mu \mathrm{M})(n=5)$ & $81.7 \pm 5.4 \%$ & vs $10 \mu \mathrm{m}$ U73122 \\
\hline U73122 (3 $\mu \mathrm{m})(n=7)$ & $70.3 \pm 3.9 \%$ & $\begin{array}{l}11.6 \pm 3.0 \%(p<0.0001) \\
24.7 \pm 5.4 \%(p<0.005) p<0.05\end{array}$ \\
\hline $\mathrm{U} 73343(3 \mu \mathrm{m})(n=5)$ & $84.0 \pm 2.6 \%$ & vs $10 \mu \mathrm{m}$ U73122 \\
\hline
\end{tabular}

Paired $t$ tests were used to compare $g_{M}$ suppression before and after the application of inhibitors in each cell studied. Unpaired $t$ tests were used to compare differences between $g_{M}$ suppression in groups of cells in the presence or absence of inhibitors. Whole-cell recordings were used in all cases.

$7 b)$. The amount of muscarine-induced $\mathrm{g}_{\mathrm{M}}$ suppression seen in the presence of U73122 thus did not differ from the amount of suppression seen in the presence of the inactive isomer $(p=0.5$; Table 4). Although at $3 \mu \mathrm{M}$ a slightly more selective effect was seen with the U73122 as compared with the inactive isomer $(p<$ 0.05; Table 4), it was not possible on the basis of these data to implicate PLC unequivocally in the action of muscarine on $\mathrm{g}_{\mathrm{M}}$ in BFSG neurons.

Despite this, the muscarine response was affected in much the same way as the ATP response by both wortmannin (Fig. 7c) and the $\mathrm{PIP}_{2}$ antiserum (Fig. $7 d, e$ ). Thus wortmannin slowed recovery of muscarine responses. Before the application of wortmannin the time for $50 \%$ recovery of responses to $2 \mu \mathrm{M}$ muscarine was $23.0 \pm 3.9 \mathrm{sec}$. This increased to $174 \pm 72.9 \mathrm{sec}$ after $10 \mathrm{~min}$ in wortmannin. After $5 \mathrm{~min}$ recording with the $\mathrm{PIP}_{2}$ antibody in the pipette, $2 \mu \mathrm{M}$ muscarine suppressed $\mathrm{g}_{\mathrm{M}}$ by $87.0 \pm 6.3 \%(n=$ 5). After $25 \mathrm{~min}$ with the antibody the muscarine became significantly less effective because it suppressed $g_{M}$ by only $64.0 \pm 8.7 \%$ $(n=5 ; p<0.002)$. In control experiments the muscarine suppressed $g_{M}$ by $82.0 \pm 4.5 \%$ after 5 min with the intracellular horse serum and by $76.6 \pm 3.0 \%$ after $25 \min (n=6 ; p>0.3)$.

The effect of muscarine and $\mathrm{P} 2 \mathrm{Y}$ agonists on $\mathrm{g}_{\mathrm{M}}$ therefore may proceed via similar mechanisms.

\section{Discussion}

The lipid kinase and PI-polyphosphate hypothesis

These experiments address the hypothesis that PLC-induced depletion of $\mathrm{PIP}_{2}$ is the signal for agonist-induced M-channel closure in BFSG neurons. This mechanism, termed the lipid kinase and PI-polyphosphate hypothesis, was suggested to explain $\mathrm{g}_{\mathrm{M}}$ inhibition by muscarinic agonists in rat sympathetic neurons (Suh and Hille, 2002; Zhang et al., 2003). Although there is now good evidence for its applicability to receptor-mediated inhibition of expressed KCNQ2/3 channels (Zhang et al., 2003), unequivocal verification of the lipid kinase and PI-polyphosphate hypothesis for agonist-induced $\mathrm{g}_{\mathrm{M}}$ suppression in an intact neu-

\footnotetext{
$\leftarrow$

tions are responses to voltage ramps (from -30 to $-110 \mathrm{mV}$ ) used to assess membrane conductance. Records of voltage commands have been omitted for clarity. $a$, Reversible reduction of $I_{\mathrm{M}}$ by $10 \mu \mathrm{m}$ muscarine and the inhibition of this effect by the PLC inhibitor U73122 (10 $\mu \mathrm{M}) . b$, Reversible reduction of $I_{\mathrm{M}}$ by $10 \mu \mathrm{m}$ muscarine and the inhibition of this effect by the inactive isomer U73343 $(10 \mu \mathrm{M})$. c, Slowing of recovery of response to $10 \mu \mathrm{M}$ muscarine by $10 \mu \mathrm{M}$ wortmannin. Arrows indicate recovery phases of muscarine responses. $d$, Responses to $2 \mu \mathrm{M}$ muscarine recorded with a pipette containing 1:100 $\mathrm{PIP}_{2}$ antibody. Left, Response obtained after $5 \mathrm{~min}$ of recording. Right, Response recorded after $25 \mathrm{~min}$ of recording. Note the preservation of steady-state $g_{M}$ as demonstrated by the unchanged amplitude of current response to voltage ramps (gray arrows) but decreased effectiveness of muscarine as demonstrated by smaller amplitude response (black arrows compared with white arrows). e, Control experiment for $d$ done with pipette containing 1:4 horse serum.
} 
ron is not yet available. The present observations therefore are discussed in relation to four testable predictions of the hypothesis. These are that (1) PLC is involved in agonist-induced $\mathrm{g}_{\mathrm{M}}$ suppression, (2) $\mathrm{g}_{\mathrm{M}}$ is increased by $\mathrm{PIP}_{2},(3) \mathrm{PIP}_{2}$ removal promotes $\mathrm{M}$-channel closure, and (4) $\mathrm{PIP}_{2}$ resynthesis is involved in the recovery of agonist-induced $\mathrm{g}_{\mathrm{M}}$ suppression.

\section{Role of PLC}

Although ATP responses are antagonized by the PLC inhibitor U73122 and not by the inactive isomer U73343 (Stemkowski et al., 2002), a preferential effect of U73122 on muscarine-induced $\mathrm{g}_{\mathrm{M}}$ inhibition was more difficult to demonstrate (Table 4). Certainly, at $3 \mu \mathrm{M}$ the active isomer seemed more effective. This is consistent with a role for PLC in muscarine-induced $g_{M}$ suppression in BFSG neurons as has been suggested in rat neurons by Suh and Hille (2002). Because $10 \mu \mathrm{M}$ U73343 failed to affect ATP responses (Stemkowski et al., 2002) yet completely blocked muscarine responses (Fig. 7b), this inactive isomer may interact with muscarinic receptors.

\section{Effects of PIP}

Although $20 \mu \mathrm{M} \mathrm{PIP}_{2}$ increased KCNQ2/3 currents in tsA-201 or COS- 1 cells (Fig. $5 c-e$ ), a somewhat higher concentration (100 $\mu \mathrm{M}$ ) produced, at best, a weak effect on $\mathrm{g}_{\mathrm{M}}$ in BFSG neurons (Fig. $5 f$, Table 2). One of many possible explanations for this difference is the presence of more membranous organelles in native neurons as compared with tsA-201 or COS cells. These could serve as sinks for exogenously applied $\mathrm{PIP}_{2}$. It also should be noted that a majority of studies of phospholipid modulation of ion channels have been performed on expressed channels (Huang et al., 1998; Xie et al., 1999; Zhang et al., 1999; Leung et al., 2000; Bian et al., 2001; Runnels et al., 2002; Rohacs et al., 2003), and few reports (Fan and Makielski, 1997; Zhang et al., 2003) document modulation of native channels by $\mathrm{PIP}_{2}$. The experiments of Zhang et al. (2003), which studied the effects of $\mathrm{PIP}_{2}$ on putative M-channels in rat sympathetic neurons, were done with inside-out patches held at $+10 \mathrm{mV}$. Similar experiments would be difficult in frog neurons because recordings at this voltage would be dominated by openings of maxi $\mathrm{g}_{\mathrm{K}, \mathrm{Ca}}$ channels (Adams et al., 1982b). We therefore used whole-cell recordings to study the effects of $\mathrm{PIP}_{2}$. The poor efficacy of exogenously applied $\mathrm{PIP}_{2}$ under these conditions did not reflect the presence of endogenous phosphatases (Huang et al., 1998), ongoing catabolism of $\mathrm{PIP}_{2}$ by the action of PLC, or saturation of possible binding sites on $\mathrm{M}$-channels by endogenous $\mathrm{PIP}_{2}$ (Table 3 ). We have noted, however, that the PLC inhibitor U73122 transiently enhances $\mathrm{g}_{\mathrm{M}}$ in BFSG cells (Stemkowski et al., 2002) (Fig. 7a). Because this effect is not seen with the inactive isomer $\mathrm{U} 73343$ (Fig. $7 b$ ), it may reflect $\mathrm{PIP}_{2}$ accumulation and increased $\mathrm{M}$-channel activity after the inhibition of basal PLC activity.

\section{$\mathrm{PIP}_{2}$ removal and $\mathrm{M}$-channel closure}

Zhang et al. (2003) reported that $\mathrm{PIP}_{2}$ antibodies inhibit KCNQ2/3 channels in inside-out oocyte macropatches. This observation is consistent with the hypothesis that $\mathrm{PIP}_{2}$ removal invokes channel closure. Our observation that $\mathrm{PIP}_{2}$ antibodies failed to affect steady-state $g_{M}$ in BFSG neurons was, therefore, unexpected. Despite this, the antibody consistently attenuated the effect of both ATP and muscarine. One explanation for this may be that the antibodies protected $\mathrm{PIP}_{2}$ from the action of PLC while preserving its interaction with $\mathrm{M}$-channels. If this were so, our result would support the hypothesis that $\mathrm{PIP}_{2}$ hydrolysis is required for agonist action. It does not, however, show that $\mathrm{PIP}_{2}$ removal invokes channel closure.

\section{$\mathrm{PIP}_{2}$ resynthesis and recovery of agonist-induced $\mathrm{g}_{\mathrm{M}}$ suppression}

Slowing of recovery of both $\mathrm{P} 2 \mathrm{Y}$ and muscarinic responses by wortmannin can be attributed to impairment of $\mathrm{PIP}_{2}$ resynthesis after the inhibition of PtdIns 4-kinase (Suh and Hille, 2002; Zhang et al., 2003). It does not reflect actions on PtdIns 3-kinase or myosin light chain kinase because inhibitors of these enzymes, LY294002 and ML7, do not mimic the effect of wortmannin. Similar mechanisms appear to operate in intact and perfused BFSG neurons because the effects of wortmannin were seen with both whole-cell and perforated-patch recording (Table 1).

Our findings differ from those of a previous study in which wortmannin had a direct inhibitory effect on $g_{M}$ in BFSG neurons that was independent of the presence of agonist (Tokimasa et al., 1995). Differences in the nucleotide content of the internal solutions used in the two studies may provide an explanation for this disparity. Whereas our internal solution contained $2 \mathrm{mM}$ ATP and no GTP, that used by Tokimasa and colleagues contained less ATP ( $1.15 \mathrm{~mm})$ and $1.5 \mathrm{~mm}$ GTP. Our solution with the relatively high ATP content would favor $\mathrm{PIP}_{2}$ synthesis (Suh and Hille, 2002), whereas the presence of GTP in the solution used by Tokimasa et al. (1995) may favor constitutive G-protein turnover, tonic activation of PLC, and hence a tendency toward $\mathrm{PIP}_{2}$ hydrolysis. The addition of wortmannin under these conditions would prevent $\mathrm{PIP}_{2}$ resynthesis, and this may explain the direct, agonist-independent action of wortmannin on $g_{M}$ observed by (Tokimasa et al., 1995). Wortmannin $(10 \mu \mathrm{M})$ also affected steady-state $g_{M}$ in rat sympathetic neurons (Suh and Hille, 2002) to a greater extent than in BFSG. This may reflect species differences. For example, there may be greater pools of $\mathrm{PIP}_{2}$ available in frog neurons as compared with rat neurons. Alternatively, the presence of a low concentration of GTP $(0.1 \mathrm{~mm})$ in the pipette solutions used by Suh and Hille (2002) may have favored ongoing PLC activity.

Inhibition of the lipid cycle at the level of DAG kinase by the use of R59022 also slowed recovery of ATP responses in BFSG neurons (Fig. 3), but this effect developed more slowly than that of wortmannin (Fig. 2a). This may reflect depletion of PIP at a relatively remote site as compared with wortmannin such that more agonist-induced turns of the cycle were required to deplete the membrane concentrations of the intermediates phosphatidic acid, CDP-DAG, PI, and PIP (Fig. 1). A further observation that is consistent with the lipid kinase and PI polyphosphate hypothesis is the slowing of the recovery of agonist responses by nonhydrolyzable ATP analogs (Suh and Hille, 2002), an effect that also occurs in BFSG neurons (Chen and Smith, 1992). These substances may reduce the activity of PtdIns 4-kinase and PtdInsP kinase by impairment of ATP hydrolysis that is required for the formation of $\mathrm{PIP}_{2}$.

\section{Transduction mechanism(s) for agonist-induced $\mathrm{g}_{\mathrm{M}}$ suppression}

Experiments reported here and in the work of Suh and Hille (2002) implicate PLC in the onset of agonist-induced suppression of $\mathrm{g}_{\mathrm{M}}$ in neurons and $\mathrm{PIP}_{2}$ resynthesis in the termination of this effect. Although the observation that $\mathrm{PIP}_{2}$ can increase neuronal $g_{M}$ (Fig. 5f) (Zhang et al., 2003) is supportive, there is, as yet, little direct evidence that the PLC-induced removal of $\mathrm{PIP}_{2}$ from M-channels is the mechanism for agonist-induced inhibition. This situation in neurons contrasts with findings in expres- 
sion systems for which Zhang et al. (2003) have presented several lines of evidence to support a role for PLC-induced removal of $\mathrm{PIP}_{2}$ from KCNQ2/3 channels as a mechanism for agonistinduced inhibition. Perhaps their most compelling observation is that mutated KCNQ channels, which display reduced sensitivity to $\mathrm{PIP}_{2}$, exhibit increased susceptibility to receptor-induced inhibition (Zhang et al., 2003). Unfortunately, manipulations of this type are not generally feasible in native neurons. Thus although there is good evidence to support the lipid kinase and PI polyphosphate hypothesis for the inhibition of expressed KCNQ2/3 channels, the physiological significance of the observations can be questioned. In contrast, the evidence from native neurons, where the physiological significance is clear, is indirect and less compelling.

In view of the clear demonstration of PLC-mediated $\mathrm{PIP}_{2}$ depletion in the mediation of muscarinic suppression of calciumpermeant TRPM7 channels in both cardiac cells and in an expression system (Runnels et al., 2002) and numerous reports of regulation of cation channel function by $\mathrm{PIP}_{2}$ (Fan and Makielski, 1997; Huang et al., 1998; Xie et al., 1999; Zhang et al., 1999; Leung et al., 2000; Bian et al., 2001; Wu et al., 2002; Rohacs et al., 2003), the hitherto elusive transduction mechanism for agonistinduced $\mathrm{g}_{\mathrm{M}}$ suppression, even in native neurons, may reflect a commonplace mechanism for channel modulation. Despite this, it is unclear whether $\mathrm{PIP}_{2}$ depletion alone is sufficient to explain the robust suppression of neuronal $g_{M}$ that is seen with all $\mathrm{G}_{\mathrm{q}^{-}}$ coupled agonists (Ikeda and Kammermeier, 2002). It is possible, for example, that the release of DAG, as a result of agonistactivation of PLC, may contribute to M-channel closure via a PKC-independent process (Chen et al., 1994). Moreover, an obligatory (Kirkwood et al., 1991; Selyanko and Brown, 1996) or permissive role of $\mathrm{Ca}^{2+}$ (Beech et al., 1991) has been discussed frequently. If a $\mathrm{Ca}^{2+}$-dependent isoform of PLC such as PLC- $\beta$ (Haley et al., 2000) is involved in the $\mathrm{PIP}_{2}$ depletion mechanism, $\mathrm{Ca}^{2+}$ released via the $\mathrm{InsP}_{3}$ pathway may serve as a positive feedback mechanism during agonist-induced $\mathrm{g}_{\mathrm{M}}$ suppression. The possible importance of $\mathrm{Ca}^{2+}$ and DAG in this process thus requires further assessment.

\section{References}

Adams PR, Brown DA, Constanti A (1982a) Pharmacological inhibition of the M-current. J Physiol (Lond) 332:223-262.

Adams PR, Constanti A, Brown DA, Clark RB (1982b) Intracellular $\mathrm{Ca}^{2+}$ activates a fast voltage-sensitive $\mathrm{K}^{+}$current in vertebrate sympathetic neurones. Nature 296:746-749.

Akasu T, Ito M, Nakano T, Schneider CR, Simmons MA, Tanaka T, Tokimasa T, Yoshida M (1993) Myosin light chain kinase occurs in bullfrog sympathetic neurons and may modulate voltage-dependent potassium currents. Neuron 11:1133-1145.

Baukrowitz T, Schulte U, Oliver D, Herlitze S, Krauter T, Tucker SJ, Ruppersberg JP, Fakler B (1998) PIP $_{2}$ and PIP as determinants for ATP inhibition of $\mathrm{K}_{\mathrm{ATP}}$ channels. Science 282:1141-1144.

Beech DJ, Bernheim L, Mathie A, Hille B (1991) Intracellular $\mathrm{Ca}^{2+}$ buffers disrupt muscarinic suppression of $\mathrm{Ca}^{2+}$ current and $\mathrm{M}$ current in rat sympathetic neurons. Proc Natl Acad Sci USA 88:652-656.

Bian J, Cui J, McDonald TV (2001) HERG K ${ }^{+}$channel activity is regulated by changes in phosphatidylinositol 4,5-bisphosphate. Circ Res 89:1168-1176.

Bofill-Cardona E, Vartian N, NanoffC, Freissmuth M, Boehm S (2000) Two different signaling mechanisms involved in the excitation of rat sympathetic neurons by uridine nucleotides. Mol Pharmacol 57:1165-1172.

Brown DA, Adams PR (1980) Muscarinic suppression of a novel voltagesensitive $\mathrm{K}^{+}$current in a vertebrate neurone. Nature 283:673-676.

Brown DA, Marrion NV, Smart TG (1989) On the transduction mechanism for muscarine-induced inhibition of M-current in cultured rat sympathetic neurones. J Physiol (Lond) 413:469-488.
Caulfield MP, Jones S, Vallis Y, Buckley NJ, Kim GD, Milligan G, Brown DA (1994) Muscarinic M-current inhibition via $\mathrm{G} \alpha \quad \mathrm{q} / 11$ and $\alpha$-adrenoceptor inhibition of $\mathrm{Ca}^{2+}$ current via $\mathrm{G} \alpha \mathrm{o}$ in rat sympathetic neurones. J Physiol (Lond) 477 :415-422.

Chen H, Smith PA (1992) M-currents in frog sympathetic ganglion cells: manipulation of membrane phosphorylation. $\mathrm{Br} \mathrm{J}$ Pharmacol 105:329-334.

Chen H, Jassar BS, Kurenny DE, Smith PA (1994) Phorbol ester-induced M-current suppression in bull-frog sympathetic ganglion cells: insensitivity to kinase inhibitors. Br J Pharmacol 113:55-62.

Chuang HH, Prescott ED, Kong H, Shields S, Jordt SE, Basbaum AI, Chao MV, Julius D (2001) Bradykinin and nerve growth factor release the capsaicin receptor from $\operatorname{PtdIns}(4,5) \mathrm{P}_{2}$-mediated inhibition. Nature 411:957-962.

Cruzblanca H, Koh DS, Hille B (1998) Bradykinin inhibits M current via phospholipase $\mathrm{C}$ and $\mathrm{Ca}^{2+}$ release from $\mathrm{IP}_{3}$-sensitive $\mathrm{Ca}^{2+}$ stores in rat sympathetic neurons. Proc Natl Acad Sci USA 95:7151-7156.

Dodd J, Horn JP (1983) A reclassification of B and C neurons in the ninth and tenth paravertebral sympathetic ganglion of the bullfrog. J Physiol (Lond) 334:255-269.

Fan Z, Makielski JC (1997) Anionic phospholipids activate ATP-sensitive potassium channels. J Biol Chem 272:5388-5395.

Ford CP, Stemkowski P, Light PE, Smith PA (2002) ATP-mediated M-channel suppression involves inositol phosphate and lipid cycles. Soc Neurosci Abstr 28:438.2.

Groul DL, Siggins GR, Padjen A, Forman DS (1981) Explant cultures of adult amphibian sympathetic ganglia: electrophysiological and pharmacological investigation of neurotransmitter and nucleotide action. Brain Res 223:81-106.

Haley JE, Abogadie FC, Delmas P, Dayrell M, Vallis Y, Milligan G, Caulfield MP, Brown DA, Buckley NJ (1998) The $\alpha$ subunit of $\mathrm{G}_{\mathrm{q}}$ contributes to muscarinic inhibition of the M-type potassium current in sympathetic neurons. J Neurosci 18:4521-4531.

Haley JE, Abogadie FC, Fernandez-Fernandez JM, Dayrell M, Buckley NJ, Brown DA (2000) Bradykinin, but not muscarinic, inhibition of $\mathrm{M}$-current in rat sympathetic ganglion neurons involves phospholipase C- $\beta 4$. J Neurosci 20:RC105(1-5).

Hilgemann DW, Ball R (1996) Regulation of cardiac $\mathrm{Na}^{+}, \mathrm{Ca}^{2+}$ exchange and $\mathrm{K}_{\mathrm{ATP}}$ potassium channels by PIP $\mathrm{P}_{2}$. Science 273:956-959.

Huang CL, Feng S, Hilgemann DW (1998) Direct activation of inward rectifier potassium channels by $\mathrm{PIP}_{2}$ and its stabilization by $\mathrm{G} \beta \gamma$. Nature 391:803-806.

Ikeda SR, Kammermeier PJ (2002) M current mystery messenger revealed? Neuron 35:411-412.

Jones SW (1987) A muscarine-resistant M-current in C cells of bullfrog sympathetic ganglia. Neurosci Lett 74:309-314.

Kirkwood A, Simmons MA, Mather RJ, Lisman J (1991) Muscarinic suppression of the $\mathrm{M}$-current is mediated by a rise in internal $\mathrm{Ca}^{2+}$ concentration. Neuron 6:1009-1014.

Kurenny DE, Chen H, Smith PA (1994) Effects of muscarine on $\mathrm{K}^{+}$channel currents in the C-cells of bullfrog sympathetic ganglion. Brain Res 658:239-251.

Leung YM, Zeng WZ, Liou HH, Solaro CR, Huang CL (2000) Phosphatidylinositol 4,5-bisphosphate and intracellular $\mathrm{pH}$ regulate the ROMK1 potassium channel via separate but interrelated mechanisms. J Biol Chem 275:10182-10189.

Liou HH, Zhou SS, Huang CL (1999) Regulation of ROMK1 channel by protein kinase A via a phosphatidylinositol 4,5-bisphosphate-dependent mechanism. Proc Natl Acad Sci USA 96:5820-5825.

Marrion NV (1997) Control of M-current. Annu Rev Physiol 59:483-504.

Nakanishi S, Kakita S, Takahashi I, Kawahara K, Tsukuda E, Sano T, Yamada K, Yoshida M, Kase H, Matsuda Y (1992) Wortmannin, a microbial product inhibitor of myosin light chain kinase. J Biol Chem 267:2157-2163.

Pfaffinger PJ, Leibowitz MD, Subers EM, Nathanson NM, Almers W, Hille B (1988) Agonists that suppress M-current elicit phosphoinositide turnover and $\mathrm{Ca}^{2+}$ transients, but these events do not explain M-current suppression. Neuron 1:477-484.

Rohacs T, Lopes CM, Jin T, Ramdya PP, Molnar Z, Logothetis DE (2003) Specificity of activation by phosphoinositides determines lipid regulation of Kir channels. Proc Natl Acad Sci USA 100:745-750. 
Runnels LW, Yue L, Clapham DE (2002) The TRPM7 channel is inactivated by $\mathrm{PIP}_{2}$ hydrolysis. Nat Cell Biol 4:329-336.

Selyanko AA, Brown DA (1996) Intracellular calcium directly inhibits potassium $\mathrm{M}$ channels in excised membrane patches from rat sympathetic neurons. Neuron 16:151-162.

Selyanko AA, Smith PA, Zidichouski JA (1990) Effects of muscarine and adrenaline on neurones from Rana pipiens sympathetic ganglia. J Physiol (Lond) 425:471-500.

Simmons MA, Schneider CR (1998) Regulation of M-type potassium current by intracellular nucleotide phosphates. J Neurosci 18:6254-6260.

Stemkowski PL, Tse FW, Peuckmann V, Ford CP, Colmers WF, Smith PA (2002) ATP inhibition of $M$ current in frog sympathetic neurons involves phospholipase $\mathrm{C}$ but not InsP $\mathrm{P}_{3}, \mathrm{Ca}^{2+}, \mathrm{PKC}$, or Ras. J Neurophysiol $88: 277-288$

Suh B, Hille B (2002) Recovery from muscarinic modulation of M current channels requires phosphatidylinositol 4,5-bisphosphate synthesis. Neuron 35:507-520.

Tokimasa T, Ito M, Simmons MA, Schneider CR, Tanaka T, Nakano T, Akasu $\mathrm{T}$ (1995) Inhibition by wortmannin of M-current in bullfrog sympathetic neurones. Br J Pharmacol 114:489-495.

Wada T, Pu J, Galles KJ, Rok BA, Makielski JC (2002) Externally applied phosphoinositides regulate $\mathrm{K}_{\mathrm{ATP}}$ and decrease glibenclamide block in intact cells. Biophys J 82:594a.
Wang HS, Pan Z, Shi W, Brown BS, Wymore RS, Cohen IS, Dixon JE, McKinnon D (1998) KCNQ2 and KCNQ3 potassium channel subunits: molecular correlates of the M-channel. Science 282:1890-1893.

Willars GB, Nahorski SR, Challiss RA (1998) Differential regulation of muscarinic acetylcholine receptor-sensitive polyphosphoinositide pools and consequences for signaling in human neuroblastoma cells. J Biol Chem 273:5037-5046.

Wu L, Bauer CS, Zhen X-G, Xie C, Yang J (2002) Dual regulation of voltagegated calcium channels by PtdIns $(4,5) \mathrm{P}_{2}$. Nature 419:947-952.

Xie LH, Horie M, Takano M (1999) Phospholipase C-linked receptors regulate the ATP-sensitive potassium channel by means of phosphatidylinositol 4,5bisphosphate metabolism. Proc Natl Acad Sci USA 96:15292-15297.

Yano H, Nakanishi S, Kimura K, Hanai N, Saitoh Y, Fukui Y, Nonomura Y, Matsuda Y (1993) Inhibition of histamine secretion by wortmannin through the blockade of phosphatidylinositol 3-kinase in RBL-2H3 cells. J Biol Chem 268:25846-25856.

Zhang H, He C, Yan X, Mirshahi T, Logothetis DE (1999) Activation of inwardly rectifying $\mathrm{K}^{+}$channels by distinct $\operatorname{Ptd} \operatorname{Ins}(4,5) \mathrm{P}_{2}$ interactions. Nat Cell Biol 1:183-188.

Zhang H, Craciun LC, Mirshahi T, Rohacs T, Lopes CM, Jin T, Logothetis DE (2003) PIP $_{2}$ activates KCNQ channels, and its hydrolysis underlies receptor-mediated inhibition of M-currents. Neuron 37:963-975. 